\title{
Herring Investigations at Plymouth. VIII. The Transition from Larva to Adolescent.
}

By

\author{
E. Ford, A.R.C.Sc., \\ Fisheries Naturalist at the Plymouth Laboratory.
}

With 12 Figures in the Text.

\section{CONTENTS.}

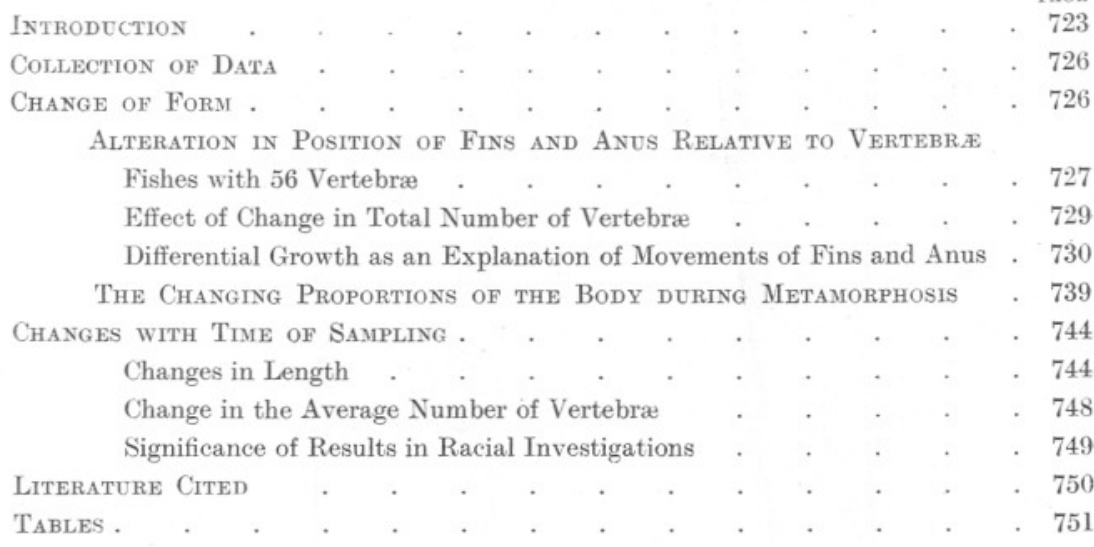

\section{INTRODUCTION.}

INVESTIGATIONS concerning the main events in the transformation of the transparent eel-shaped larval herring into the silvery and scaled adolescent fish may proceed along two lines. In the first place, information may be sought as to the biological processes which bring about each event. For example, attention may be directed to the study of the differential growth of the body by which the form of the adult is attained; or, to the manner in which the scales are developed. But, secondly, it is of vital importance to learn how much the events of metamorphosis are affected by circumstances of time and place. Thus, at Plymouth, as elsewhere, we need to know the extent of possible differences in form and size between young fishes which have metamorphosed from larvæ born at different times.

Sufficient material has been collected from the rivers flowing into the sea at Plymouth to yield information along both the above lines of investigation. In the first section of this paper attention is given to the 


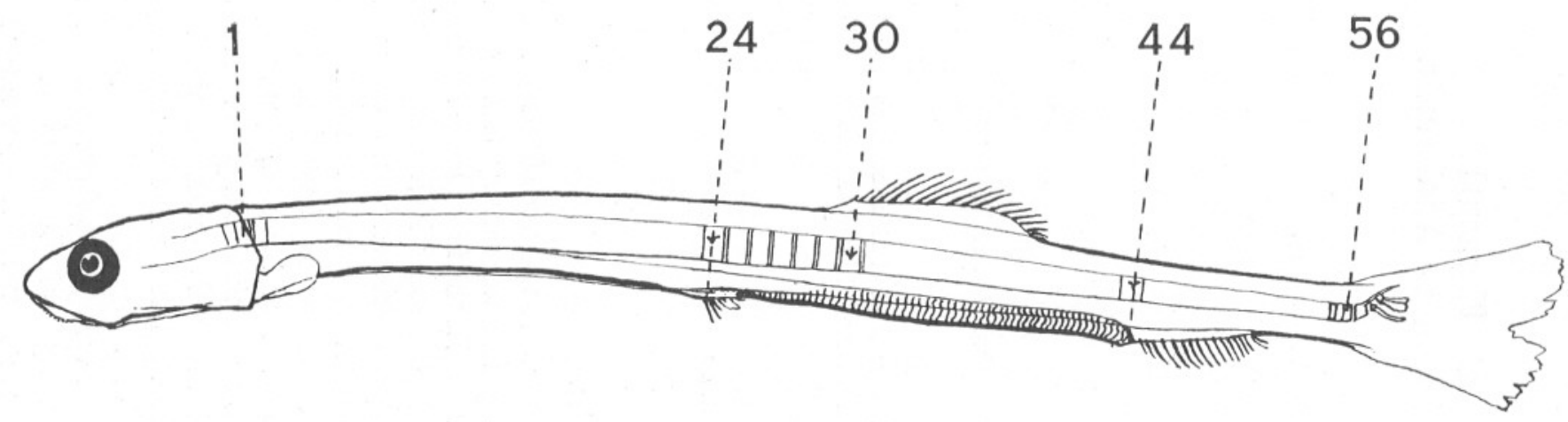

FIG. 1.-Semi-diagrammatic drawing of post-larval herring. Body-length $\left(\mathrm{L}_{\mathrm{B}}\right)$ of $33 \mathrm{~mm}$. Position of pelvies, first dorsal ray and anus with respect to vertebræ. Total number of vertebræ is 56 , exclusive of compound urostyle.

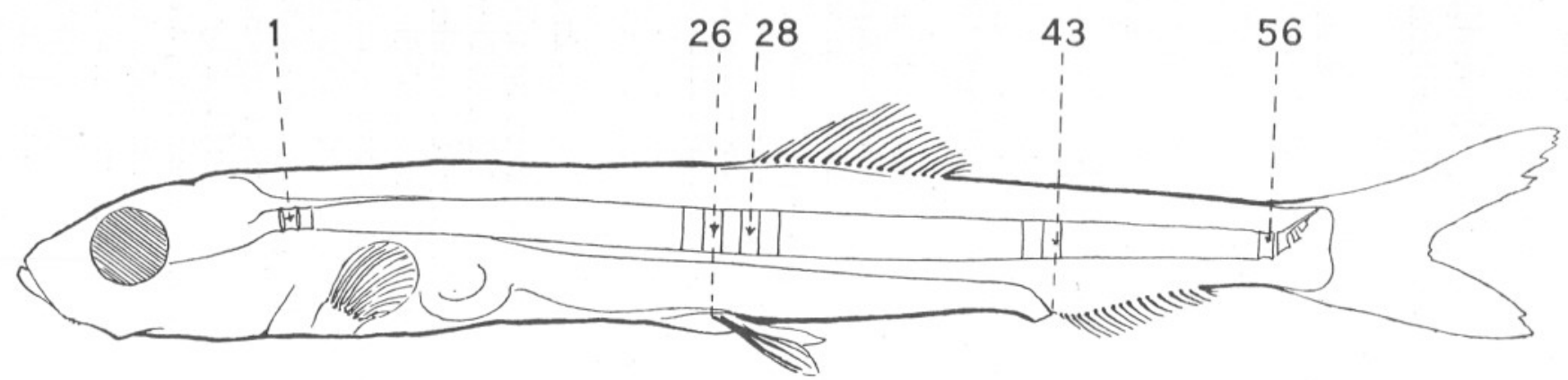

FIG. 2.-Post-larval herring; body-length $\left(\mathrm{L}_{\mathrm{B}}\right)$ of $36 \mathrm{~mm}$. Note apparent movement of pelvics, dorsal fin and anus with respect to vertebræ. 


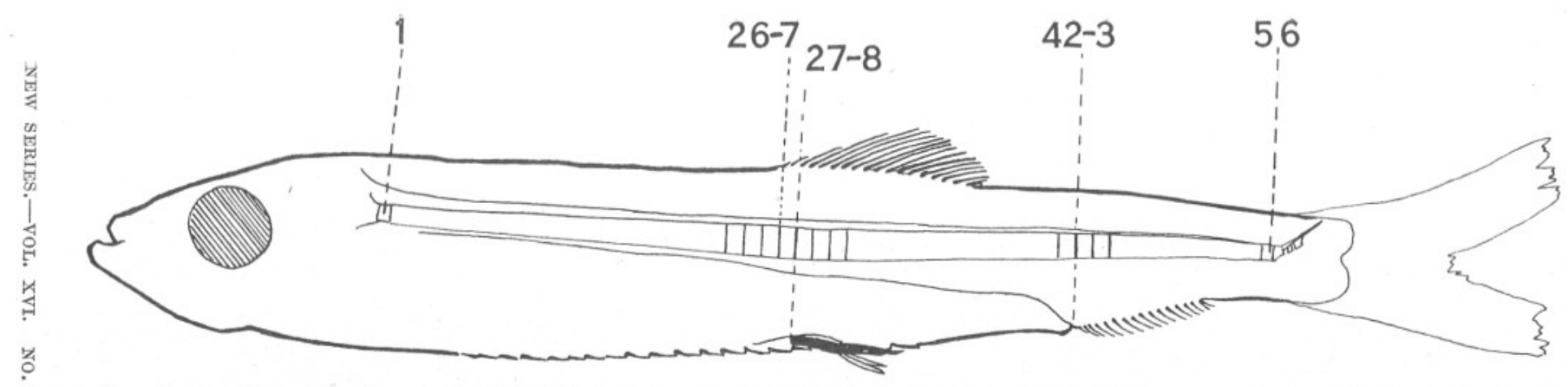

FIG. 3.-Post-larval herring; body-length $\left(\mathrm{L}_{\mathrm{B}}\right)$ of $37 \mathrm{~mm}$. Pelvics now lie slightly farther back than first dorsal ray with respect to vertebræ. Anus has moved still farther forward.

5

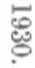

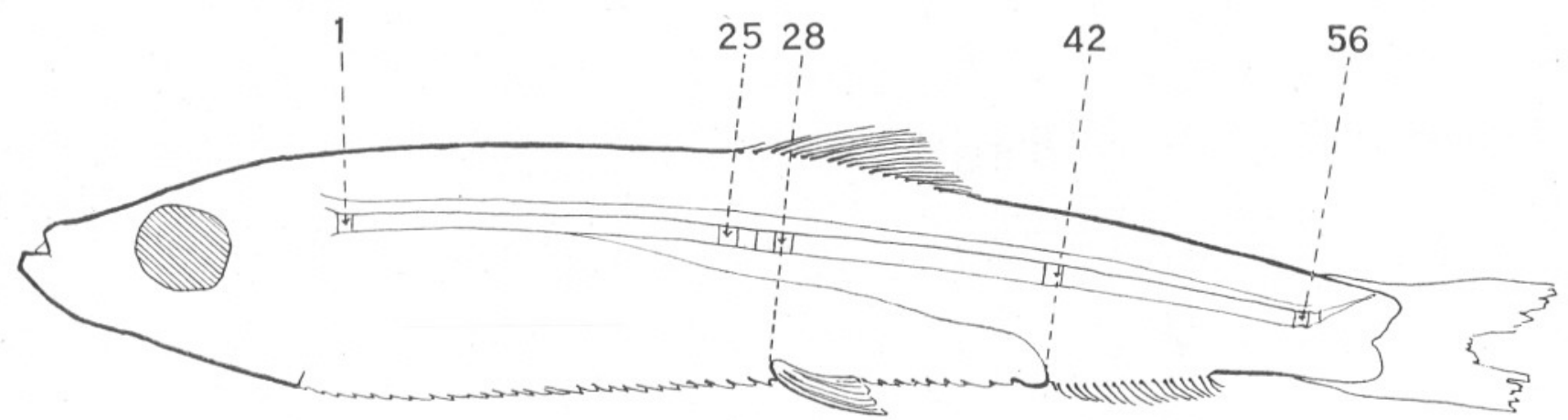

Fis. 4.-Post-larval herring; body-length $\left(\mathrm{L}_{\mathrm{B}}\right) 45 \mathrm{~mm}$. Pelvies well behind first dorsal ray, and anus beneath vertebra 42. 
question of the differential growth of the body, while in the second, problems arising out of observed differences between samples of metamorphosing fishes are discussed.

\section{Collection of Data.}

The fishes studied were caught in a small-meshed Saltash tuck-seine in the Rivers Tamar and Lynher [charts of the district are given by Ford (3) and Percival (6)]. As a measure of length, the body-length $\mathrm{L}_{\mathrm{B}}$ from the tip of the snout to the end of the caudal peduncle, was used in preference to the more familiar total-length $\mathrm{L}_{\mathrm{T}}$, for reasons previously stated in Ford (3, p. 307). The value of $\mathrm{L}_{\mathrm{T}}$ is approximately equal to $7 / 6 \mathrm{~L}_{\mathrm{B}}$. The method of statistical "grouping" was also the same as that hitherto used; e.g. fishes from 30 to $34 \mathrm{~mm}$. would be grouped in the $30 \mathrm{~mm}$. group, and those from 35 to $39 \mathrm{~mm}$. in the $35 \mathrm{~mm}$. group, when grouping was by intervals of $5 \mathrm{~mm}$. For the first part of the work, fifty specimens of each of the four body-length groups $30 \mathrm{~mm}$., $35 \mathrm{~mm}$., $40 \mathrm{~mm}$., and $45 \mathrm{~mm}$. from any one day's sample were utilised. These were stained in alizarin either whole, or after the excision of one side by means of a safety-razor blade, and then cleared in xylol. A count of the total number of vertebræ in each specimen was made, and the position, either immediately above or below a particular vertebra, of the first dorsal fin-ray, the pelvics and the anus noted. The count of the total number of vertebræ stopped at the vertebra immediately preceding the compound urostyle (vide Ford, 2, p. 253). In determining the relative position of the fins and anus, it frequently happened that the structure concerned occupied a position opposite the interval between two adjacent vertebræ. In such cases an entry of $\frac{1}{2}$ was made to each of the appropriate vertebræ classes. At a later stage in the work, actual measurements along the body to determine well-defined body intervals were made on specimens prior to staining.

\section{CHANGE OF FORM.}

\section{Alteration in Position of Fins and Anus Relative TO VERTEBRA.}

Fage (1) and Lebour (5) have shown that in the gradual adjustment of the fins and anus of the larva to the positions they occupy in the adult, these structures alter their place with respect to the vertebræ.* Thus

\footnotetext{
* Since this paper has been in the hands of the printer, the important work by Dr. Schnakenbeck on the development of the herring has appeared. (Entwicklungsgeschichtliche und morphologische Untersuchungen am Hering. Berichte d. Deutsch. wissenschaftl. Komm. f. Meeresforschung, Neue Folge, Band V Heft 2, Berlin, 1929.) Dr. Schnakenbeck has studied the process of metamorphosis in relation to the growth of the myotomes. Excellent illustrations are given.
} 
there is a relative movement forward of the dorsal fin and anus, but a backward one of the pelvics. In order to assist those readers who may not be familiar with these facts, Figures 1, 2, 3, and 4 have been inserted. But as individual fishes differ in their total number of vertebræ from 53 to 58 , it is clearly of importance to study the effect of this difference in total with regard to the relative movements of fins and anus. For example, the 25th vertebra, under which the pelvics may lie in a fish having a total of 55 vertebræ, is not in the same relative position along. the vertebral column as the 25th vertebra of a second fish having 57 vertebræ. Hence, in analysing the progress of development over a range of time or size, it is necessary to take into account the total number of vertebræ of the individuals concerned.

\section{Fishes with 56 Vertebra.}

It is convenient to commence with those fishes which form the greater proportion of each sample taken, namely, those with a total of 56 vertebræ. Data are available for a total of 746 such fishes caught during the months of April, May and June, and varying in body-length from 30 to $49 \mathrm{~mm}$. The position of the pelvics in these specimens varies from beneath the 24 th vertebra to beneath the 29 th. The variation in position of the first dorsal ray $\left(D^{1}\right)$ when the pelvics lie under the 24 th, 25 th to the 29 th vertebra respectively is given in the following table :-

\section{TABLE I.}

\begin{tabular}{|c|c|c|c|c|c|c|c|c|c|c|}
\hline \multirow[t]{2}{*}{$\begin{array}{l}\text { Position } \\
\text { of Pelvics. } \\
\text { No. of } \\
\text { specimens } \\
\text { in which } \\
\text { pelvics lie } \\
\text { beneath } \\
\text { vertebræ } \\
\text { as under. }\end{array}$} & & No. of & $\begin{array}{r}\text { Pos } \\
\text { cimens }\end{array}$ & $\begin{array}{l}\text { of of } 1 \\
\text { which }\end{array}$ & $\begin{array}{l}\text { Dorsa } \\
\text { 'lies a }\end{array}$ & $\begin{array}{l}\text { ay }\left(\mathbf{D}^{1}\right. \\
\text { e vert }\end{array}$ & as $u$ & & \multirow[t]{2}{*}{ Totals. } & \multirow[t]{2}{*}{$\begin{array}{c}\text { Position } \\
\text { of D } \\
\text { Working } \\
\text { means. }\end{array}$} \\
\hline & 24 & 25 & 26 & 27 & 28 & 29 & 30 & 31 & & \\
\hline 24 & - & - & - & - & - & - & 2 & - & 2 & $29 \cdot 5^{*}$ \\
\hline $24-25$ & - & - & - & - & $\frac{1}{2}$ & 3 & $6 \frac{1}{2}$ & 3 & 13 & $29 \cdot 42$ \\
\hline 25 & - & - & - & 1 & $3 \frac{1}{2}$ & $23 \frac{1}{2}$ & $33^{2}$ & 9 & 70 & $29 \cdot 15$ \\
\hline $25-26$ & - & - & - & $1 \frac{1}{2}$ & $2^{2}$ & $13 \frac{1}{2}$ & 6 & 5 & 28 & $28 \cdot 89$ \\
\hline 26 & - & - & $8 \frac{1}{2}$ & $16 \frac{1}{2}$ & $37 \frac{1}{2}$ & $46^{2}$ & 29 & $2 \frac{1}{2}$ & 140 & $28 \cdot 06$ \\
\hline $26-27$ & - & 1 & $8^{2}$ & $10^{2}$ & $16 \frac{2}{2}$ & 8 & $\frac{1}{2}$ & - & 44 & 27.05 \\
\hline 27 & $2 \frac{1}{2}$ & 26 & $60 \frac{1}{2}$ & $57 \frac{1}{2}$ & $20^{2}$ & $3 \frac{1}{2}$ & 1 & - & 171 & $25 \cdot 97$ \\
\hline $27-28$ & $1^{2}$ & $25 \frac{1}{2}$ & $19 \frac{2}{2}$ & $5 \frac{2}{2}$ & $3 \frac{1}{2}$ & - & - & - & 55 & $25 \cdot 23$ \\
\hline 28 & $3 \frac{1}{2}$ & $75^{2}$ & $90^{2}$ & $4 \frac{1}{2}$ & - & - & - & - & 173 & $25 \cdot 05$ \\
\hline $28-29$ & - & 8 & 23 & 1 & - & - & - & - & 32 & $25 \cdot 28$ \\
\hline 29 & - & $6 \frac{1}{2}$ & 10 & $\frac{1}{2}$ & - & - & - & - & 17 & $25 \cdot 15$ \\
\hline Totals & 7 & 142 & $219 \frac{1}{2}$ & 98 & $83 \frac{1}{2}$ & $97 \frac{1}{2}$ & 78 & $19 \frac{1}{2}$ & 745 & \\
\hline
\end{tabular}

* For statistical purposes, the middle of the 30 th vertebra is regarded as point $29 \cdot 5$, and similarly from each of the other means, 0.5 is subtracted. 
In Figure 5, below, the mean positions of $\mathrm{D}^{1}$ given in the right-hand column of Table I are plotted against the successive positions of the pelvics (curve $\mathrm{AB}$ ), while the straight line CD is simply the result of plotting the positions of the pelvics both as ordinates and abscissæ. It will be seen that $\mathrm{AB}$ and $\mathrm{CD}$ cross at point 26.35 ; that is to say, the first dorsal ray is vertically above the pelvics at this point

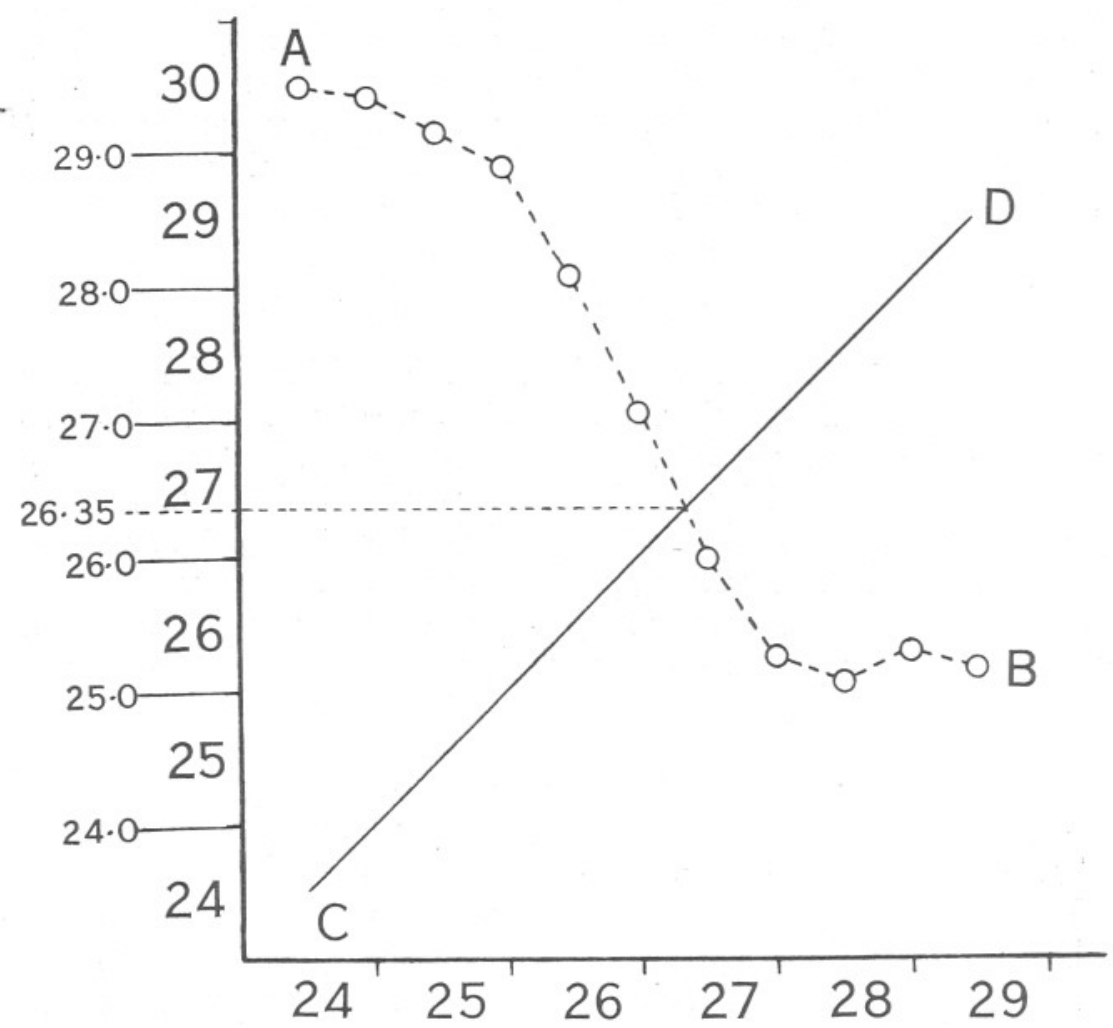

Fig. 5.-The positions of first dorsal ray (ordinates) for observed positions of pelvics (abscissæ) with respect to vertebræ, in fishes with a total of 56 vertebræ, are shown in the graph $\mathrm{AB}$. The successive positions of the pelvics are represented by the straight line CD. The pelvies lie immediately beneath the first dorsal ray at point 26.35 along the vertebral column; i.e. at the level of the anterior part of the 27 th vertebra (see text above).

which is approximately the middle of the $27 \mathrm{th}$ vertebra. It is also apparent that the dorsal fin and the pelvics continue their movement beyond this stage, so that finally the first dorsal ray comes to lie several vertebræ in front of the pelvics, in contrast with its original position well behind the latter.

Corresponding data for fishes with 56 vertebræ on the position of 
the anus with respect to pelvics and vertebræ are given in Table II below :-

\begin{tabular}{|c|c|c|c|c|c|c|c|c|}
\hline \multirow[t]{2}{*}{$\begin{array}{l}\text { Position } \\
\text { of Pelvics. } \\
\text { No. of } \\
\text { specimens } \\
\text { in which } \\
\text { pelvics lie } \\
\text { beneath } \\
\text { vertebrex } \\
\text { as under. }\end{array}$} & \multicolumn{6}{|c|}{$\begin{array}{l}\text { Position of Anus, } \\
\text { No. of Specimens in which Anus lies beneath vertebre } \\
\text { as under. }\end{array}$} & & \multirow{2}{*}{$\begin{array}{c}\text { Position } \\
\text { of Anus. } \\
\text { Workin } \\
\text { means. }\end{array}$} \\
\hline & 41 & 42 & $43^{a}$ & $\begin{array}{l}\text { nader. } \\
44\end{array}$ & 45 & 46 & Totals. & \\
\hline 24 & - & - & - & 1 & $\frac{1}{2}$ & $\frac{1}{2}$ & 2 & $44 \cdot 25^{*}$ \\
\hline $24-25$ & - & - & 4 & 6 & $2 \frac{1}{2}$ & $\frac{1}{2}$ & 13 & $43 \cdot 46$ \\
\hline 25 & - & 1 & $30 \frac{1}{2}$ & $26 \frac{1}{2}$ & $11 \frac{1}{2}$ & $\frac{1}{2}$ & 70 & $43 \cdot 21$ \\
\hline $25-26$ & - & 1 & $14 \frac{1}{2}$ & $7 \frac{2}{2}$ & 5 & - & 28 & 43.09 \\
\hline 26 & $2 \frac{1}{2}$ & $46 \frac{1}{2}$ & $63^{2}$ & $22 \frac{2}{2}$ & $5 \frac{1}{2}$ & - & 140 & $42 \cdot 37$ \\
\hline $26-27$ & 1 & $18 \frac{1}{2}$ & $19 \frac{1}{2}$ & $4 \frac{1}{2}$ & $\frac{1}{2}$ & - & 44 & $42 \cdot 14$ \\
\hline 27 & $4 \frac{1}{2}$ & $87 \frac{1}{2}$ & $73 \frac{1}{2}$ & $4 \frac{1}{2}$ & $-{ }^{2}$ & - & 170 & $41 \cdot 96$ \\
\hline $27-28$ & 1 & $31 \frac{1}{2}$ & $22 \frac{1}{2}$ & $1 \frac{1}{2}$ & $\frac{1}{2}$ & - & 57 & $41 \cdot 96$ \\
\hline 28 & $2 \frac{1}{2}$ & $68 \frac{2}{2}$ & $97 \frac{2}{2}$ & $4 \frac{1}{2}$ & $-{ }^{2}$ & - & 173 & $42 \cdot 10$ \\
\hline 28-29 & - & $10^{\circ}$ & $22^{2}$ & - & - & - & 32 & $42 \cdot 19$ \\
\hline 29 & - & 5 & 11 & 1 & - & - & 17 & $42 \cdot 26$ \\
\hline Totals & $11 \frac{1}{2}$ & $269 \frac{1}{2}$ & 358 & $79 \frac{1}{2}$ & 26 & $1 \frac{1}{2}$ & 746 & \\
\hline
\end{tabular}

The mean positions of the anus are plotted against the successive positions of the pelvics in Figure 6 on page 730 . By erecting a perpendicular at point 26.35 along the horizontal axis, and noting the ordinate of the point $\mathrm{E}$ at which the perpendicular intersects the curve, we can determine the mean position of the anus when the first dorsal ray is immediately above the pelvics. This occurs when the anus is at point 42.0 or, in other words, when the anus is midway between the 42 nd and the 43rd vertebræ. By this time, unlike the dorsal fin, the anus has practically completed its forward movement.

It may not have escaped notice that the curves for both the dorsal fin and anus tend to rise slightly at the right-hand end. This suggests that a slight reversal of the direction of movement relative to vertebræ may take place towards the end of metamorphosis.

\section{Effect of Change in Total Number of Vertebroe.}

Data on the position of the first dorsal ray and anus with respect to the pelvics, for fishes with 55 or 57 vertebræ, are given in Tables VII and VIII at the end of this paper. These are summarised graphically in Figure 7, in which the effects of a change in the total number of vertebræ are clearly demonstrated. It is seen that the higher the total number of vertebræ the higher are the mean values for the position of both $D^{1}$ and anus for any given position of the pelvics. Thus, the mean position along 
the vertebral column at which $\mathrm{D}^{1}$ is vertically over the pelvics, and the position of the anus at that time, in the three cases is as follows :-

$\begin{array}{ccc}\begin{array}{c}\text { Total No. } \\ \text { of vertebræ. }\end{array} & D^{1} \text { and Pelvics. } & \text { Anus. } \\ 55 & 26 \cdot 05 & 41 \cdot 5 \\ 56 & 26 \cdot 35 & 42 \cdot 0 \\ 57 & 26 \cdot 60 & 42 \cdot 6\end{array}$

\section{Differential Growth as an Explanation of Movements of Fins and Anus.}

No proof is here needed of the elementary fact that during the greater part of the relative changes in position of fins and anus, the fish as a whole increases in length. Furthermore, mere inspection first of a larva and then of a newly-metamorphosed fish suffices to verify the fact that

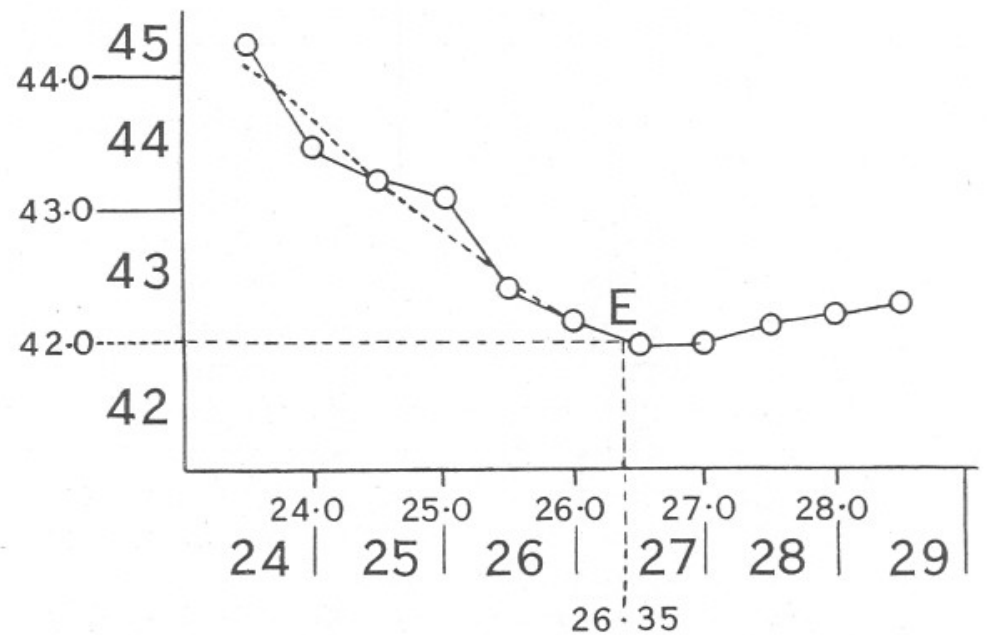

FIG. 6.-The positions of the anus (ordinates) for observed positions of pelvics (abscissæ) with respect to vertebræ, in specimens with a total of 56 vertebræ. The position of the anus when the first dorsal ray is vertically above the pelvics is given by the ordinate of point $\mathrm{E}$, namely, point 42.0 along the vertical column (i.e. beneath the junction of the 42 nd and 43rd vertebræ), see text, page 729 .

the various body-intervals such as the distance from the pelvies to the anus, or from the anus to the end of the caudal peduncle, form a markedly different proportion of the whole length in the two cases. It would seem a simple additional step to measure selected body-intervals for successive stages in position of fins and anus, and thus to determine in absolute units of length, the growth of each body-interval throughout metamorphosis. The data of the present time-series of samples, however, do not lend themselves to so simple statistical treatment, since the length at which any 
given phase of metamorphosis is reached varies over a wide range, and there is much overlap in length among the different phases. The extent and significance of these differences in length form a study of their own and are discussed in a later section of this paper. Despite the fact that

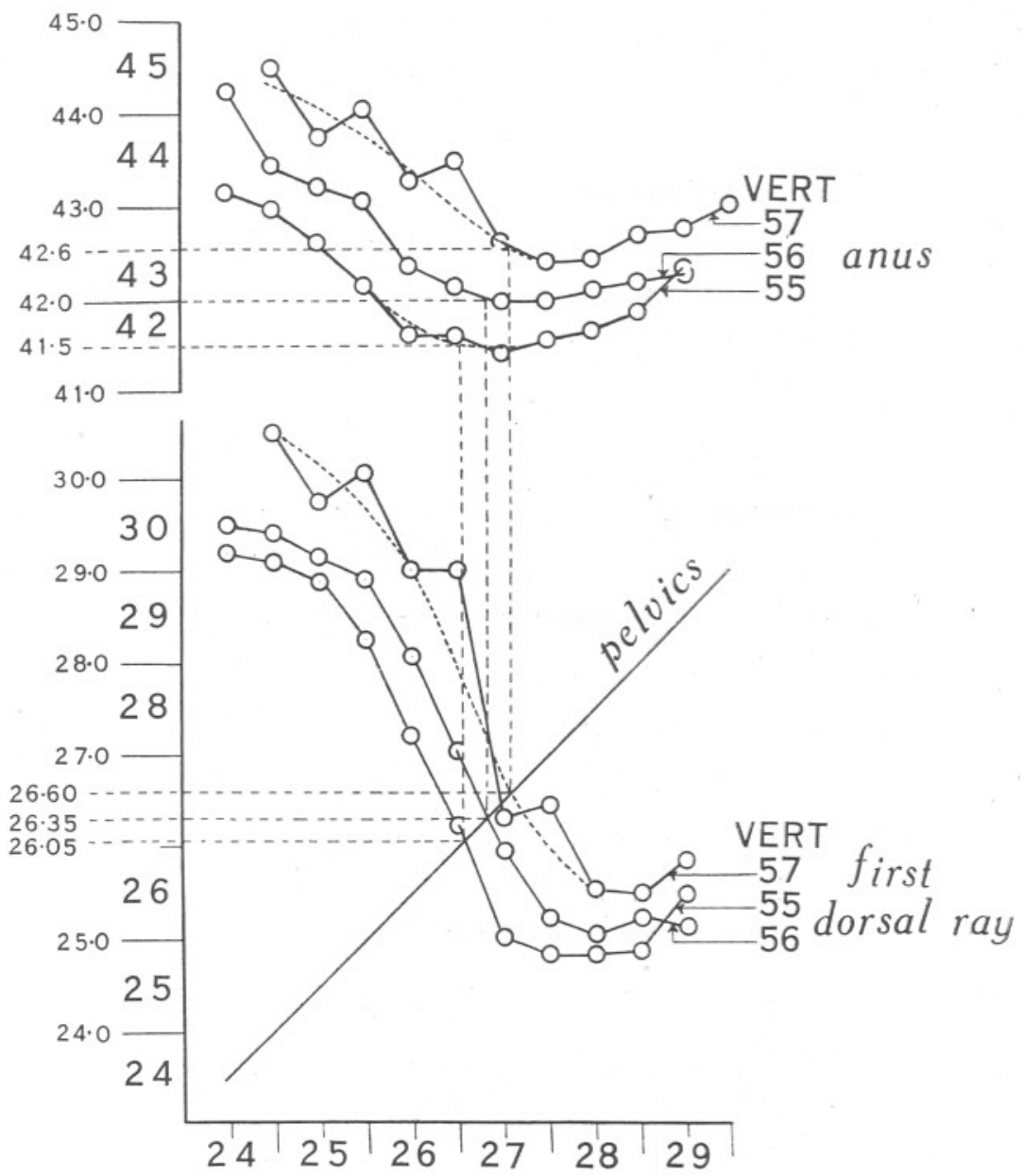

Frg. 7.-Positions of the first dorsal ray and anus (ordinates) for observed positions of the pelvics (abscissæ) with respect to vertebræ in fishes having 55, 56, and 57 vertebræ respectively. The diagram is merely a composite one, combining the results of figures corresponding with those shown in Figs. 5 and 6.

individuals at the same phase of metamorphosis vary in absolute length, it is still possible to watch the change in proportionate length shown by given body-intervals from phase to phase. It is found that while some intervals increase in proportion, others decrease. Now a decreasing 
proportion as metamorphosis proceeds may indicate one of three things. In the first place, the body-interval may be actually decreasing in length ; secondly, it may be remaining quite stationary throughout; or thirdly, it may be increasing in absolute length but at a slower rate than the fish as a whole. A study of the available data has shown that the distance from the pelvics to the anus, and from the back of the brain to the insertion of the first dorsal ray, both undergo a marked reduction in
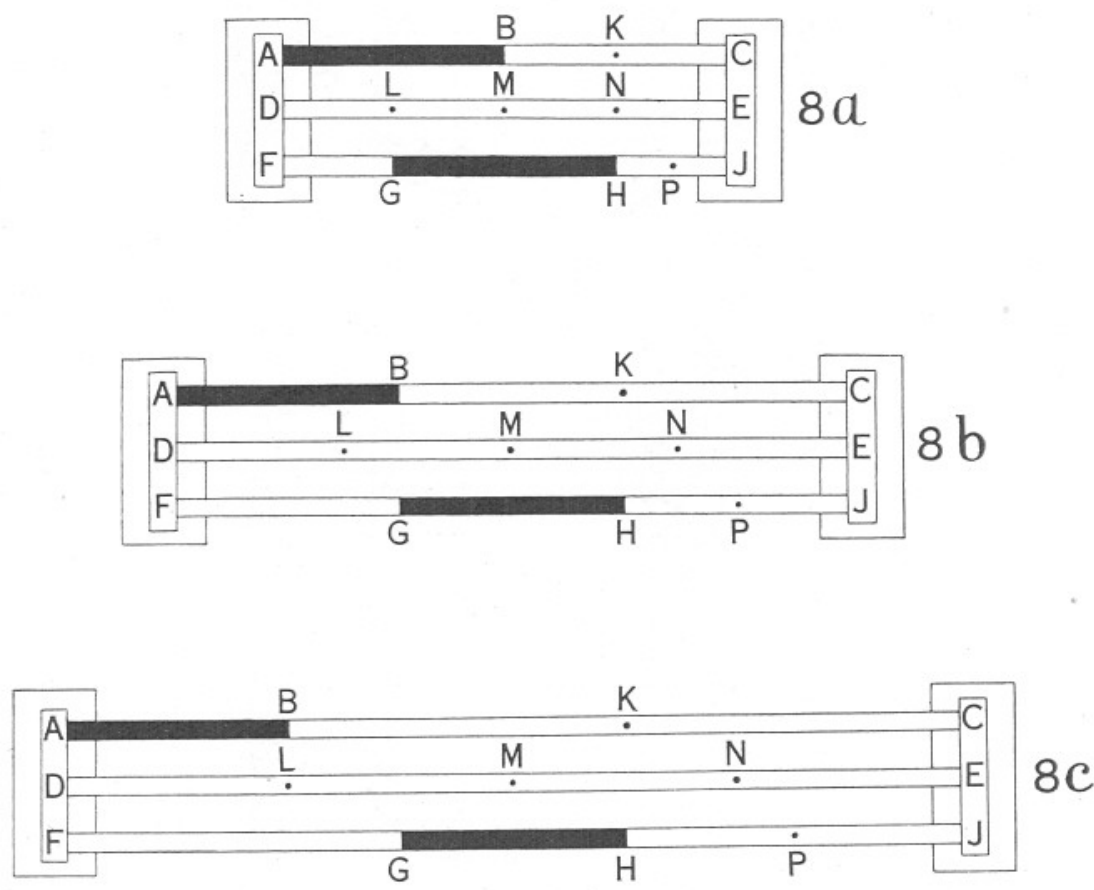

FIG. 8.-Diagrams illustrating the results of stretching the model composed of tape and elastic described in the text below.

8A.-Unstretched model. Portions $\mathrm{AB}$ and $\mathrm{GH}$ are constructed of rigid tape ; the remaining parts of the three horizontal components are elastic. Total length is 4 units. 8B.-Model stretched to a total length of 6 units.

8c.-Model stretched to a total length of 8 units.

proportion as development proceeds. This observation, as will be realised later, is of great significance as an aid to the understanding of the mechanism of growth during metamorphosis, and in order to demonstrate this point the more clearly, the reader is asked to devote patient attention to the action of some simple models constructed of tape and elastic. The first model is rectangular in form as shown in Figure 8a. It consists essentially of three parallel components $\mathrm{AC}, \mathrm{DE}$ and $\mathrm{FJ}$, each four units in length, connected at their ends by wooden stays AF and CJ. 
The uppermost component $\mathrm{AC}$ consists of a tape portion $\mathrm{AB}$ of two units in length, and an elastic portion $\mathrm{BC}$, also two units in length. The middle component DE is entirely elastic, being merely marked off into four equal sections at points $\mathrm{L}, \mathrm{M}$ and $\mathrm{N}$. The third component FJ consists of a portion of tape $\mathrm{GH}$ two units long, inserted between single units of elastic FG and HJ. The positions of different points along $\mathrm{AC}$ and $\mathrm{FJ}$ may be expressed either in units of length from the wooden end AF, or with respect to their position above or below points in any one of the three components. Thus, with the model in its unstretched condition, the following positions may be noted :-

\begin{tabular}{|c|c|c|}
\hline Point. & $\begin{array}{l}\text { Distance from AF } \\
\text { in units. }\end{array}$ & $\begin{array}{l}\text { Position with reference to points } \\
\text { in other components. }\end{array}$ \\
\hline$B$ & 2 & Directly above point $\mathrm{M}$ \\
\hline G & 1 & below,, $\mathrm{L}$ \\
\hline $\mathrm{H}$ & 3 & $\mathrm{~N}$ \\
\hline
\end{tabular}

By holding the wooden ends AF and CJ and pulling outwards, the three components may be stretched equally to a new length. As an initial stretching, let the total length be increased from four units to six. Figure $8 \mathrm{~b}$ represents the new situation. The positions of the three points B, G and $\mathrm{H}$ are now seen to be :-

$\begin{array}{ccc}\begin{array}{c}\text { Point. } \\ \text { B }\end{array} & \begin{array}{c}\text { Distance from AF } \\ \text { in units. }\end{array} & \begin{array}{c}\text { Position with reference to points } \\ \text { in other components. } \\ \text { Directly above point G; } \\ \text { above but to the left of } \\ \text { point M. }\end{array} \\ \text { G } & 2 & \begin{array}{l}\text { Directly below point B ; } \\ \text { above but to the right of } \\ \text { point L. } \\ \text { Below but to the left of } \\ \text { point N. }\end{array} \\ \text { H } & 4 & \end{array}$

A further stretching is now applied so that the total length becomes eight units. Figure $8 \mathrm{c}$ reproduces the model at this stage, and the final positions of points $\mathrm{B}, \mathrm{G}$ and $\mathrm{H}$ are :-

$\begin{array}{ccc}\begin{array}{c}\text { Point. } \\ \text { B }\end{array} & \begin{array}{c}\text { Distance from AF } \\ \text { in units. }\end{array} & \begin{array}{c}\text { Position with reference to points } \\ \text { in other components. } \\ \text { Directly above point } \mathrm{L} \text {; } \\ \text { above but to the left of } \\ \text { point G. }\end{array} \\ \text { G } & 2 & \begin{array}{l}\text { Below mid-point between } \\ \text { points L and M. } \\ \text { Below mid-point between } \\ \text { points M and N. }\end{array}\end{array}$


Thus, as the result of these two stretchings, the appearance of the model has been greatly changed, and points $B, G$ and $H$ have altered their positions relative to one another and to points along the middle component DE. In addition, the proportions of various parts of the three
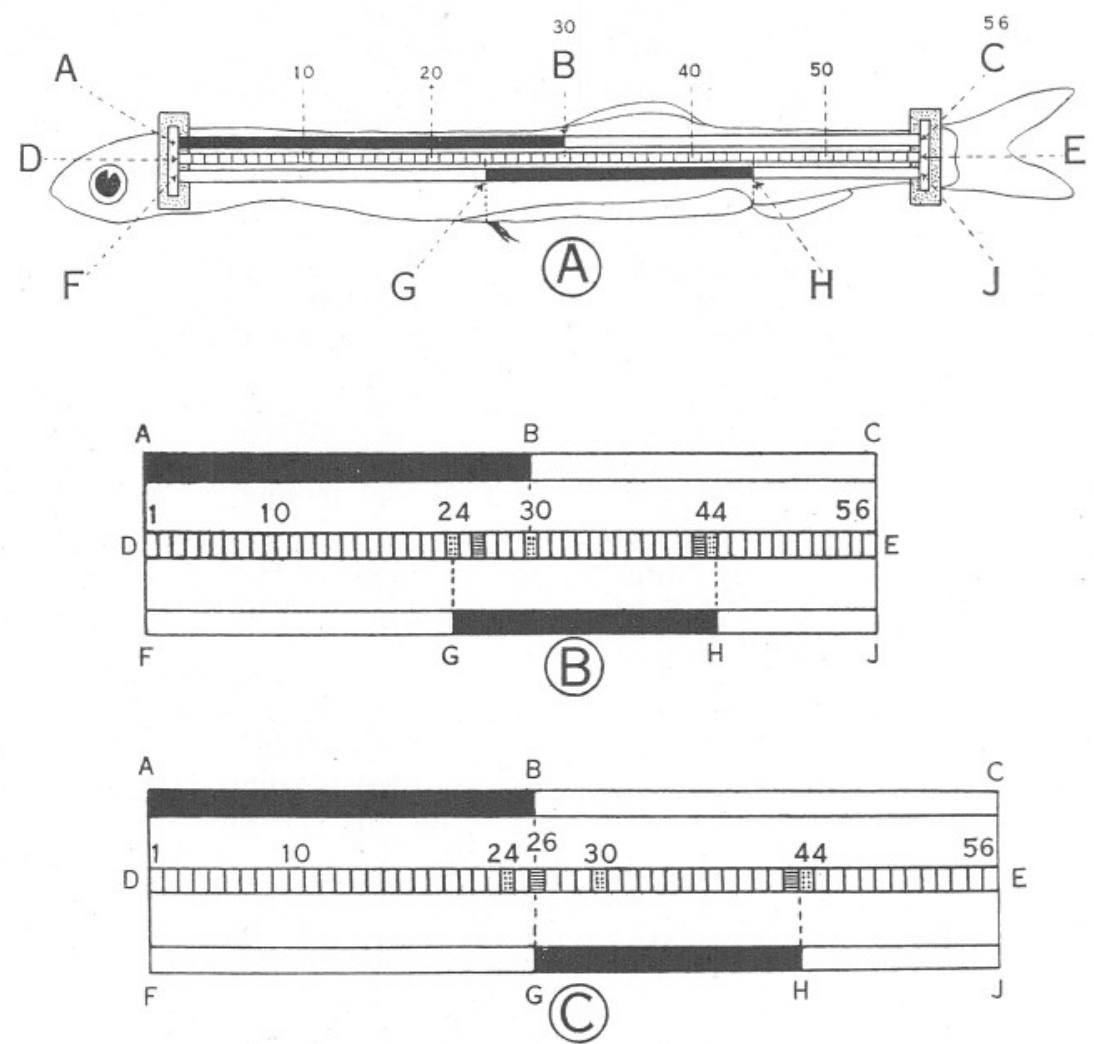

Fig. 9A.-A tape and elastic model, similar in character to that shown in Fig. $8 \mathrm{~A}$, is here superimposed on a diagrammatic representation of a post-larval herring, so that points $\mathrm{B}, \mathrm{G}$, and $\mathrm{H}$ coincide with the pelvics, first dorsal ray and anus respectively with respect to the vertebræ.

FIG. 9B.-Diagram of the model thus created. The middle component is divided into 56 equal parts to represent 56 vertebræ; point B lies above the middle of the 30 th vertebra, point $G$ beneath the middle of the 24 th vertebra and point $H$ beneath the junction of the 44 th and 45 th vertebræ.

FIG. 9c.-Diagram representing the model when stretched to a length of $65 \cdot 1$ units as compared with its original length of 56 units. Note how the positions of points B, $\mathrm{G}$ and $\mathrm{H}$ with respect to vertebræ have changed as the result of stretching.

components have also changed. Dealing first with component AC, it is seen that point $B$ has moved to the left from above point $M$ to above point $\mathrm{L}$, while the distance $\mathrm{AB}$ has become reduced in proportion from one-half the total length to one-quarter. Simultaneously, $\mathrm{BC}$ has increased in proportion from one-half to three-quarters. The component 
DE being entirely elastic extends uniformly throughout its length, so that points $\mathrm{L}, \mathrm{M}$ and $\mathrm{N}$ remain unaltered in relative position along DE. The composite component FJ, on the other hand, has undergone alteration; the elastic portions FG and HJ have each increased from one-fourth of the total length to three-eights, while the rigid tape portion $\mathrm{GH}$ has become reduced in proportion from one-half to onequarter. As the result, point $\mathrm{G}$ has moved to the right from its original position beneath point $\mathrm{L}$ to a new one between points $\mathrm{L}$ and $\mathrm{M}$; and point $\mathrm{H}$ to the left from beneath point $\mathrm{N}$ to between points $\mathrm{N}$ and $\mathrm{M}$.

In Figure $9 \mathrm{~A}$ a three-component rectangular model is shown superimposed over a diagrammatic outline of a larval herring, so that the different portions of the model roughly represent the body-intervals of the fish over which they fall. In this way we may experiment with a model approximating to the correct proportions of the fish itself. It is seen that this model is only an elaborated counterpart of the simple model just considered, in which point $B$ now represents the position of the first dorsal ray, G coincides with the insertion of the pelvics, and $\mathrm{H}$ with the anus. The component $\mathrm{DE}$ is here divided into as many blocks as there are vertebræ in the fish-and it may be taken in this instance that there are 56 vertebræ. As before, portions $\mathrm{AB}$ and $\mathrm{GH}$ in the model can be regarded as rigid and represented by tape, while the remainder is of elastic. For the sake of simplicity, also, all the vertebræ may be considered equal in size (length). Referring back to the data in Tables I and II (pp. 727 and 729) it is noted that with the pelvics situated beneath the middle of the 24th vertebra, the first dorsal ray (represented by point $\mathrm{B}$ in the model) lies opposite the middle of the 30th vertebra, and the anus (point $\mathrm{H}$ in the model) below the junction of the 44th and 45 th vertebræ.

As there are 56 vertebræ in the fish, it will be convenient to regard the total length, AC, of the model as 56 units, so that the dimensions of the model can at once be stated :-

$\begin{array}{cccccc}\text { Intervals } & \mathrm{AB} & \mathrm{BC} & \mathrm{FG} & \mathrm{GH} & \mathrm{HJ} \\ \text { Units of length } & 29 \cdot 5 & 26 \cdot 5 & 23 \cdot 5 & 20 \cdot 5 & 12 \cdot 0\end{array}$

It is obvious that by stretching the model, points $\mathrm{B}$ and $\mathrm{H}$, as in the simple model, will move to the left, relative to points along the centre component DE, and point $\mathrm{G}$ to the right. That is to say that the first dorsal ray and the anus will make a forward movement over the vertebræ while the pelvics shift backwards. This is in accordance with fact (p. 727). If stretching is carried sufficiently far, point B (representing the first dorsal ray) can be brought immediately over point $\mathrm{G}$ (representing the pelvics). It is possible to calculate the new total length to which the model must be stretched to reproduce this phase, and also the points 
along the vertebral column over which the first dorsal ray, the pelvies, and the anus lie :-

Let the new length of the model be $\mathrm{x}$.

Since $\mathrm{AB}$ and $\mathrm{GH}$ are non-elastic, their lengths remain unaltered throughout the stretching.

With the model in its stretched condition, its dimensions are :

$\begin{array}{lccccc}\text { Intervals } & \mathrm{AB} & \mathrm{BC} & \mathrm{FG} & \mathrm{GH} & \text { HJ } \\ \text { Units of } & 29 \cdot 5 & (\mathrm{x}-29 \cdot 5) & \frac{(\mathrm{x}-20 \cdot 5)(23 \cdot 5)}{(23 \cdot 5+12 \cdot 0)} & & \frac{(\mathrm{x}-20 \cdot 5)(12 \cdot 0)}{(23 \cdot 5+12 \cdot 0)} \\ \text { length } & & & \frac{(20)}{(23+12 \cdot 0)}\end{array}$

In this condition $\mathrm{AB}=\mathrm{FG}$, or $29 \cdot 5=\frac{(\mathrm{x}-20 \cdot 5)(23 \cdot 5)}{(23 \cdot 5+12 \cdot 0)}$

$\therefore \mathrm{x}=65 \cdot 1$

Substituting the value $65 \cdot 1$ for $\mathrm{x}$ in the above table of dimension :-

$\begin{array}{cccccc}\text { Intervals } & \mathrm{AB} & \mathrm{BC} & \mathrm{FG} & \mathrm{GH} & \mathrm{HJ} \\ \text { Units of length } & 29 \cdot 5 & 35 \cdot 6 & 29 \cdot 5 & 20 \cdot 5 & 15 \cdot 1\end{array}$

The positions with respect to the vertebræ of points $\mathrm{B}, \mathrm{G}$ and $\mathrm{H}$ are given by :-

Position of $\mathrm{B}$ and $\mathrm{G} \frac{29 \cdot 5}{65 \cdot 1} \times 56=25 \cdot 4 \begin{aligned} & \text { (i.e. practically opposite the middle } \\ & \text { of the } 26 \text { th vertebra.) }\end{aligned}$

Position of $\mathrm{H} \quad \frac{(29 \cdot 5+20 \cdot 5)}{65 \cdot 1}{ }^{(56)}=43 \cdot 0 \quad \begin{gathered}\text { (i.e. opposite the junction of } \\ \text { 43rd and 44th vertebræ.) }\end{gathered}$

Referring back to the data given on page 728 it is seen that the first dorsal ray passes the pelvics at the level of the 27 th vertebra, the anus being then at the level of the 43rd vertebra. The model then (see Figs. $9 \mathrm{~b}$ and c), has brought point B (representing the first dorsal ray) forward at rather too quick a rate, and point $\mathrm{H}$ (representing the anus) too slowly, although it has rightly made the total shift greatest in the case of point $B$ (the first dorsal ray).

It was shown on page 730 that the position along the vertebral column at which the first dorsal ray is vertically above the pelvics, and the position of the anus at that time is dependent upon the total number of vertebræ (vide Table on p. 730 and Fig. 7 on p. 731). It is easy to see from the model how this could arise, for an alteration in the number of vertebræ means a changing of the number of subdivisions of the middle component DE. With the model stretched to a length of $65 \cdot 1$ units, the intervals along the components $\mathrm{AC}$ and $\mathrm{FJ}$ will be precisely the same whatever the number of parts into which the centre component $\mathrm{DE}$ is divided. Thus, point $\mathrm{B}$ will lie immediately above point $\mathrm{G}$ at a 


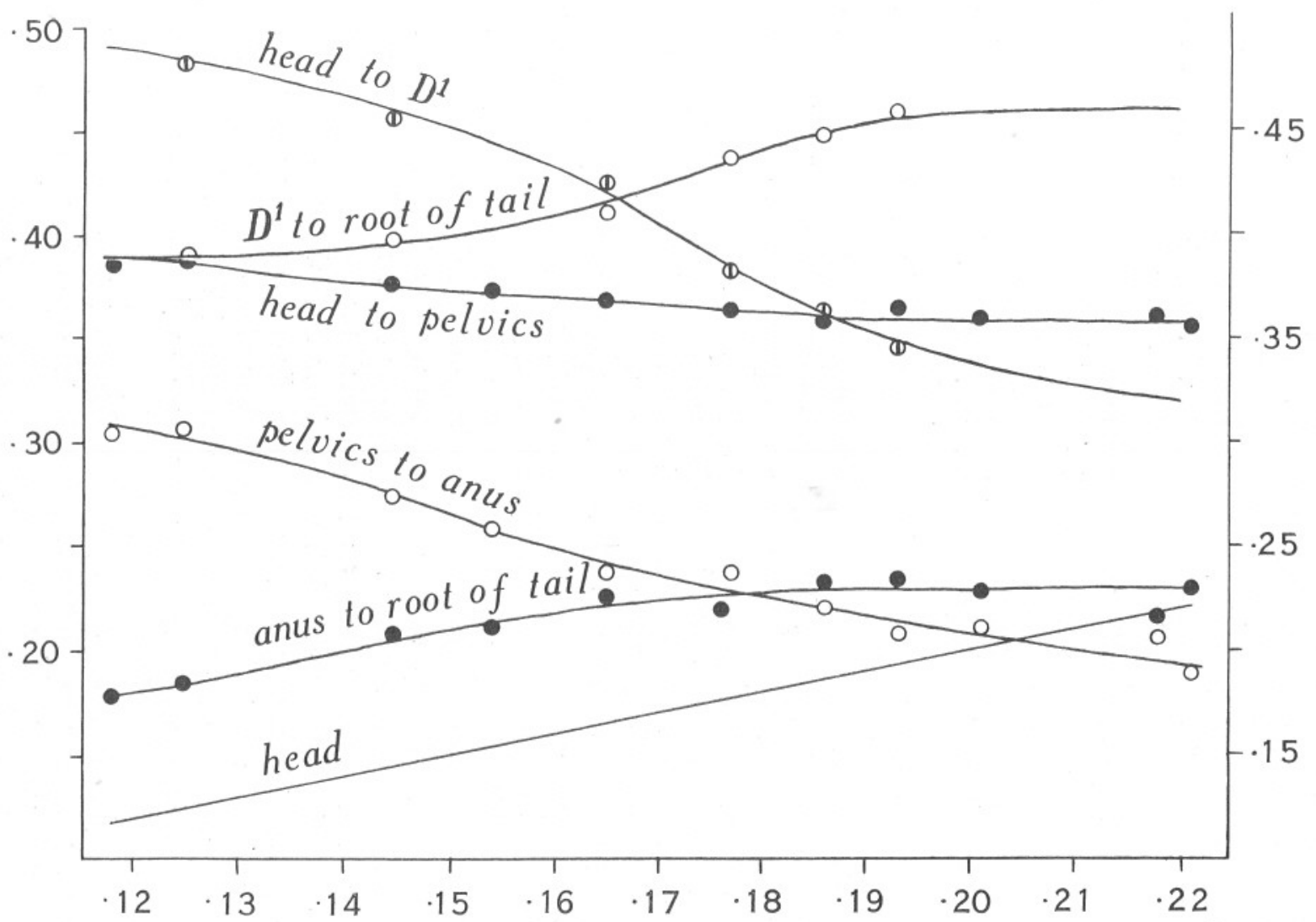

Fig. 10.-Curves showing the proportions of various body-intervals for successive values of the proportion of the head (abscissæ). See Table III on page 739. 
distance of 29.5 units from the origin regardless of the division of $\mathrm{DE}$ into 55, 56, or 57 parts. But the position along DE to which B and $\mathrm{G}$ are opposite will not be the same in the three cases :-

1. When $\mathrm{DE}$ is divided into 55 parts, points $\mathrm{B}$ and $\mathrm{G}$ will lie opposite point . . . $\quad 29.5 \times 55$ $65 \cdot 1=24 \cdot 9$ along DE

2. When $\mathrm{DE}$ is divided into 56 parts, points $\mathrm{B}$ and $\mathrm{G}$ will lie opposite point . ' . . $\frac{29 \cdot 5 \times 56}{65 \cdot 1}=25 \cdot 4$ along DE

3. When $\mathrm{DE}$ is divided into 57 parts, points $\mathrm{B}$ and $G$ will lie opposite point $\frac{29 \cdot 5 \times 57}{65 \cdot 1}=25 \cdot 8$ along DE

Hence the model, like the direct observations on the fish themselves, shows that the higher the number of vertebræ, the higher are the values for the positions of the first dorsal ray, the pelvies and the anus at the same phase of development.

The model is also useful in the study of the change in position relative to vertebræ of the dorsal and anal fins in their entirety. Referring to Figure 8a, the base of the dorsal fin is represented by the anterior portion BK of the component BC. During stretching, point B moves forward with respect to the vertebræ while point $\mathrm{C}$ obviously does not. Clearly then, any point between $\mathrm{B}$ and $\mathrm{C}$ will make some forward movement, the amount depending upon the relative distance of the point from B. Thus point $\mathrm{K}$, representing the hinder end of the base of the dorsal fin, will move forward relative to the vertebræ, but not so quickly as point $B$. As the result of stretching, the dorsal fin as a whole will appear to move forward and will also tend to cover more and more vertebræ as stretching continues. Similarly with the anal fin. Point $\mathrm{H}$ at the anterior end of component HJ moves forward, while point $\mathrm{J}$ remains at rest relative to the vertebræ; point $\mathrm{P}$ representing the posterior end of the anal fin will move forward, but at a slower rate than $\mathrm{H}$. Thus the anal fin will tend to move forward and to cover more vertebræ as stretching is applied.

Summarising, it may be said that an elementary model incorporating three distinct systems of differential growth, viz., along the dorsal surface, along the vertebral column and along the ventral surface, respectively, will broadly speaking reproduce the salient features of the relative movements of fins and anus during metamorphosis. 


\section{The Changing Proportions of the Body during Metamorphosis.}

In the foregoing considerations, attention has been centred mainly on the alteration in relative position of definite points along the dorsal and ventral surfaces of the body and along the vertebral column. It is now necessary to consider the changing proportions of the body-intervals between the moving points. The curves shown in Figure 10 on page 737 are based on data derived from actual measurements of approximately 500 fishes in different phases of metamorphosis, so selected that the whole sequence of transition from the nude post-larva to the scaled and silvery adolescent was represented. The lengths of the different intervals along each fish were determined by direct measurement on a squared rule under magnification, and the absolute measurements then converted into proportions of the body-length $\mathrm{L}_{\mathrm{B}}$ of the fish. The resulting data were finally summarised according to the proportionate length of the head, which increases as metamorphosis proceeds, and the mean results were plotted as shown in Figure 10. From these curves the following Table of Values has been prepared :-

\section{TABLE III}

\begin{tabular}{|c|c|c|c|c|c|}
\hline LENGTh o & CERTAIN & $\begin{array}{l}\text { BODY-INTEI } \\
\text { OF BODY-I }\end{array}$ & $\begin{array}{l}\text { LXS EXPR } \\
\text { GTH }\left(\mathrm{L}_{\mathrm{B}}\right)\end{array}$ & SED AS & ROPORTIONS \\
\hline $\begin{array}{l}\text { Head (tip of } \\
\text { snout to back } \\
\text { of brain). }\end{array}$ & Head to $D^{1}$. & $\begin{array}{c}\mathrm{D}^{1} \text { to end of } \\
\text { caudal } \\
\text { peduncle. }\end{array}$ & $\begin{array}{l}\text { Head to } \\
\text { pelvics. }\end{array}$ & $\begin{array}{l}\text { Pelvics } \\
\text { to anus. }\end{array}$ & $\begin{array}{l}\text { Anus to end of } \\
\text { caudal } \\
\text { peduncle. }\end{array}$ \\
\hline .12 & $\cdot 490$ & $\cdot 390$ & $\cdot 390$ & .305 & $\cdot 185$ \\
\hline$\cdot 13$ & $\cdot 479$ & $\cdot 391$ & $\cdot 384$ & .295 & $\cdot 190$ \\
\hline$\cdot 14$ & $\cdot 466$ & $\cdot 394$ & $\cdot 378$ & $\cdot 284$ & ·199 \\
\hline$\cdot 15$ & $\cdot 450$ & $\cdot 400$ & $\cdot 374$ & $\cdot 265$ & $\cdot 210$ \\
\hline$\cdot 16$ & $\cdot 430$ & $\cdot 410$ & $\cdot 370$ & .248 & .218 \\
\hline$\cdot 17$ & .405 & .425 & .366 & .237 & .225 \\
\hline$\cdot 18$ & $\cdot 378$ & $\cdot 442$ & $\cdot 362$ & .230 & .228 \\
\hline$\cdot 18 \%$ & $\cdot 361$ & .452 & $\cdot 361$ & .223 & .229 \\
\hline$\cdot 19$ & $\cdot 355$ & $\cdot 455$ & $\cdot 360$ & $\cdot 217$ & 2230 \\
\hline$\cdot 20$ & $\cdot 340$ & $\cdot 460$ & $\cdot 359$ & $\cdot 210$ & $\cdot 230$ \\
\hline$\cdot 21$ & $\cdot 330$ & $\cdot 460$ & $\cdot 358$ & $\cdot 202$ & $\cdot 230$ \\
\hline$\cdot 22$ & $\cdot 320$ & $\cdot 460$ & $\cdot 357$ & ·193 & .230 \\
\hline
\end{tabular}

Attention is first directed to the phase of metamorphosis when the first dorsal ray $\left(\mathrm{D}^{1}\right)$ lies immediately above the pelvics, i.e. when the distance from the head to the pelvics is equal to that from the head to $\mathrm{D}^{1}$. It is seen from the above Table that when this occurs the head constitutes $\cdot 187$ of the body-length. At this stage, also, the length from 
the anus to the end of the caudal peduncle has reached a proportionate length slightly exceeding that from the pelvics to anus.

It is of particular interest here to go back to the use of models similar to those employed in previous discussions. The first model, represented in Figure 1la, is similar to that shown in Figure 8a, save that the central component DE need not be used in the present instance, and its dimensions are in accordance with the data in the above Table when the head comprises $\cdot 12$ of the body-length :-

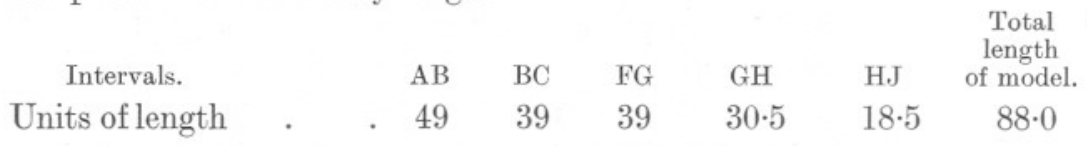

As before, $\mathrm{AB}$ and $\mathrm{GH}$ are assumed to be non-elastic and therefore represented by tape, while the remaining intervals are represented by the correct lengths of elastic of uniform grade. The calculated dimensions of this model when it is stretched until $\mathrm{AB}$ is equal to $\mathrm{FG}$, as in Figure 11c (representing the phase when the first dorsal ray is vertically over the pelvics) are :-

\begin{tabular}{|c|c|c|c|c|c|c|c|}
\hline Intervals. & & $\mathrm{AB}$ & $\mathrm{BC}$ & FG & $\mathrm{GH}$ & HJ & $\begin{array}{l}\text { length } \\
\text { of model. }\end{array}$ \\
\hline Units of length & . & . 49 & $53 \cdot 8$ & 49 & $30 \cdot 5$ & $23 \cdot 3$ & $102 \cdot 8$ \\
\hline
\end{tabular}

The head of the fish at this phase comprises $\cdot 187$ of the body-length $\mathrm{L}_{\mathrm{B}}$. The total length of the model (102.8 units) thus represents $\cdot 813 \mathrm{~L}_{\mathrm{B}}$, so that $\mathrm{L}_{\mathrm{B}}=\frac{102 \cdot 8}{\cdot 813}=126 \cdot 4$ units.

The proportions of the body-intervals as actually determined from measurements of fish, and as represented by the model are, thus, as follows :-

\begin{tabular}{|c|c|c|c|c|c|c|c|}
\hline Head. & & & $\begin{array}{c}\text { Head } \\
\text { to } \mathrm{D}^{1} \\
(\mathrm{AB})\end{array}$ & $\begin{array}{c}\mathrm{D}^{1} \text { to } \\
\text { end of } \\
\text { caudal } \\
\text {.peduncle. } \\
\text { (BC) }\end{array}$ & $\begin{array}{c}\text { Head } \\
\text { to } \\
\text { pelvics. } \\
\text { (FG) }\end{array}$ & $\begin{array}{l}\text { Pelvics } \\
\text { to } \\
\text { anus. } \\
\text { (GH) }\end{array}$ & $\begin{array}{c}\text { Anus to } \\
\text { end of } \\
\text { caudal } \\
\text { peduncle. } \\
\text { (HJ) }\end{array}$ \\
\hline ctual $\cdot 187$ & . & $\cdot$ & $\cdot 361$ & $\cdot 452$ & $\cdot 361$ & $\cdot 223$ & $\cdot 229$ \\
\hline Iodel - & . & $\theta^{\circ}$ & $\cdot 388$ & .426 & $\cdot 388$ & $\cdot 241$ & $\cdot 184$ \\
\hline
\end{tabular}

It is evident that the model has not reproduced the results from measurements; $\mathrm{AB}, \mathrm{FG}$, and $\mathrm{GH}$ are too large, while $\mathrm{BC}$ and $\mathrm{HJ}$ are too small.

A little experimenting with the model will show that the insertion of a stiffer elastic for the interval FG has an important effect. The model will now have to be stretched to a greater length in order to bring point $\mathrm{B}$ over $\mathrm{G}$, and as the result, intervals $\mathrm{AB}, \mathrm{FG}$ and $\mathrm{GH}$ will be 

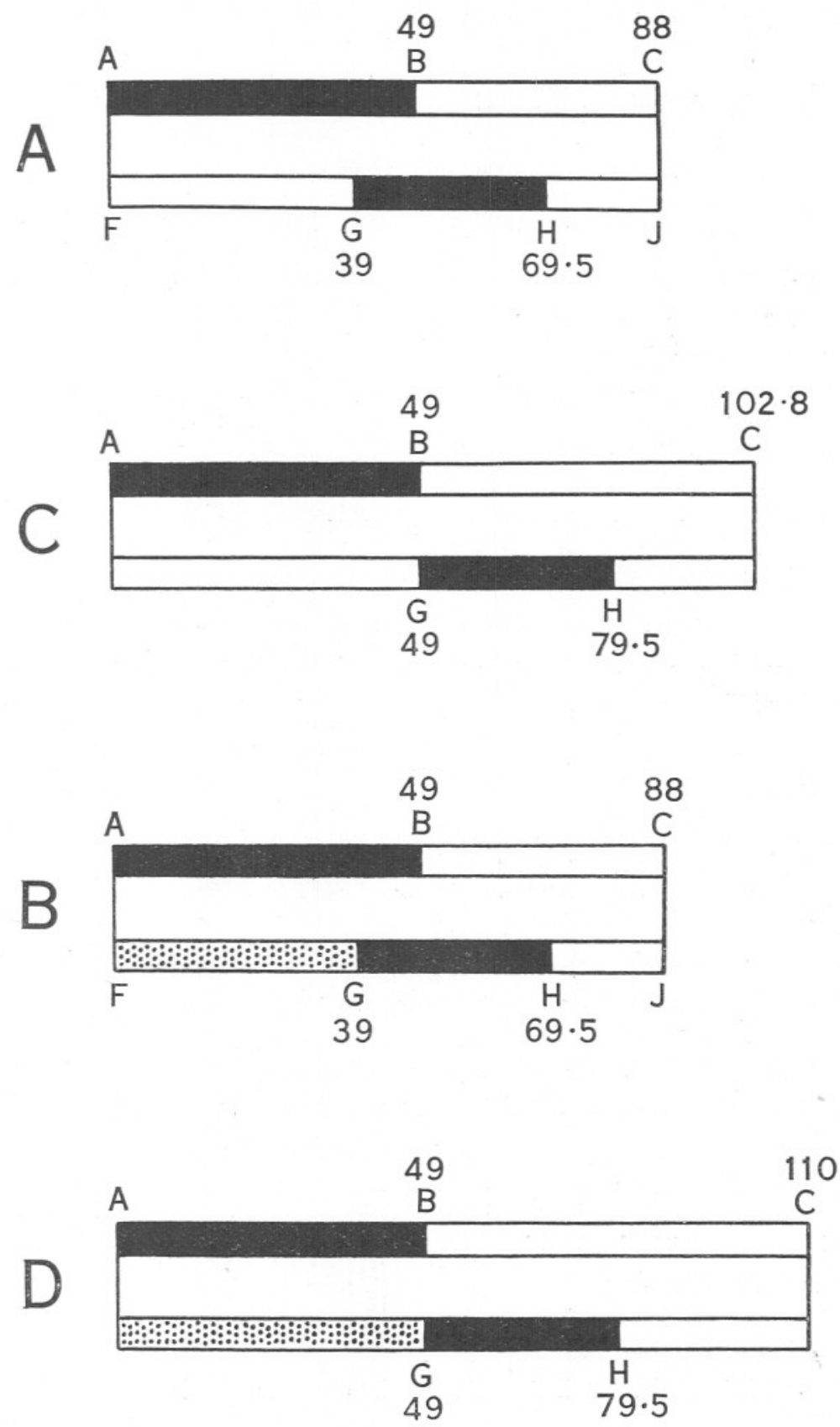

FIG. 11A.-Tape and elastic model described in text on page 740. In this case the interval FG is constructed of elastic similar in stretching quality to the elastic used in the other parts of the model.

Fig. 11B.-A second tape and elastic model, similar in dimensions to that shown in Fig. 11. but differing in that the interval FG is constructed of an elastic $\frac{11}{10}$ times as resistant as the elastic used in other components. This difference is indicated by stippling.

FIG. 1lc.-The model shown in Fig. $11 \mathrm{~A}$ is here stretched until point G lies immediately beneath point $B$. The total length of the model is 102.8 units.

FiG. 11n.-The model shown in Fig. 11 в is here stretched until point G lies immediately beneath point $B$. The total length of the model is 110 units.

NEW SERIES.-VOL. XVI. NO. 3. MAY. 1930. 
proportionally reduced, while $\mathrm{BC}$ and $\mathrm{HJ}$ will be increased. Now this is just what is required if the model is to reproduce an exact picture of actual measurements. Imagine then, that $\mathrm{BC}$ is constructed of a stiffer elastic of such stretching capacity that it is $\frac{11}{10}$ as resistant to strain as the elastic of which BC and HJ are constructed (Fig. 11b). With this new model stretched until point B is above G (Fig. 11d) the calculated dimensions are :-

$\begin{array}{cccccc}\text { AB } & \text { BC } & \text { FG } & \text { GH } & \text { HJ } & \begin{array}{c}\text { Total length } \\ \text { of model. }\end{array} \\ 49 & 61 & 49 & 30.5 & 30.5 & 110 \cdot 0\end{array}$

The new length of the model, $110 \cdot 0$, represents $\cdot 813 \mathrm{~L}_{\mathrm{B}}$, and therefore $\mathrm{L}_{\mathrm{B}}$ is $\frac{110}{.813}=135 \cdot 3$ units.

The proportions of the different intervals of the body as represented by the new model, as compared with actual fish measurements may now be given :-

Head.

Actual $\cdot 187$

New model -

$\begin{array}{ccccc} & \begin{array}{c}\mathrm{D}^{1} \text { to } \\ \text { end of } \\ \text { caudal }\end{array} & \begin{array}{c}\text { Head } \\ \text { to }\end{array} & \begin{array}{c}\text { Pelvics } \\ \text { to }\end{array} & \begin{array}{c}\text { Anus to } \\ \text { end of } \\ \text { caudal } \\ \text { Head } \\ \text { cauduncle. }\end{array} \\ \text { to } \mathrm{D}^{1} \text { peduncle. } & \text { pelvics. } & \text { anus. } & \text { peduncle. } \\ (\mathrm{AB}) & (\mathrm{BC}) & (\mathrm{FG}) & (\mathrm{GH}) & \text { (HJ) }\end{array}$

$\cdot 361 \quad \cdot 452 \quad \cdot 361 \quad \cdot 223$

$.362 \cdot 225$

Hence, by the mere substitution of stiffer elastic for the interval BC, the model has been made to reproduce a very satisfactory picture of actual measurements.

By dividing the absolute length of an interval after stretching by its original length, an idea may be obtained of the relative increase made :-

\begin{tabular}{|c|c|c|c|c|c|c|}
\hline Head. & $\begin{array}{l}\text { Head } \\
\text { to } \mathrm{D}^{1} \text {. } \\
(\mathrm{AB})\end{array}$ & $\begin{array}{c}\mathrm{D}^{1} \text { to } \\
\text { end of } \\
\text { caudal } \\
\text { peduncle. } \\
\text { (BC) }\end{array}$ & $\begin{array}{c}\text { Head } \\
\text { to } \\
\text { pelvics. } \\
\text { (FG) }\end{array}$ & $\begin{array}{l}\text { Pelvics } \\
\text { to } \\
\text { anus. } \\
\text { (GH) }\end{array}$ & $\begin{array}{c}\text { Anus to } \\
\text { end of } \\
\text { caudal } \\
\text { peduncle. } \\
\text { (HJ) }\end{array}$ & - $L_{B}$ \\
\hline Before stretching & & & & & & \\
\hline $\begin{array}{c}1 \cdot 0 \\
\text { fter stretching }\end{array}$ & $1 \cdot 0$ & $1 \cdot 0$ & $1 \cdot 0$ & $1 \cdot 0$ & $1 \cdot 0$ & $1 \cdot 0$ \\
\hline $2 \cdot 11$ & $1 \cdot 0$ & $1 \cdot 56$ & $1 \cdot 26$ & $1 \cdot 0$ & $1 \cdot 65$ & 1.54 \\
\hline
\end{tabular}

These figures are instructive as showing that with the exception of the two intervals $\mathrm{AB}$ and $\mathrm{GH}$ which were not allowed to stretch at all, each of the other intervals has enlarged at a rate of its own. The head and the interval HJ have grown at a rate considerably faster than that 
of the fish as a whole, whereas BC has grown at approximately the same rate as the fish as a whole, while FG has increased at a much slower rate than these others.

So far, however, growth has only been carried far enough to bring the first dorsal ray above the pelvics, but it has already been shown at an earlier stage that the first dorsal ray travels still farther forward and the pelvics backward, before metamorphosis is complete. Let the model, therefore, be further stretched until its total length is 119.5 units. The lengths of the body-intervals will then be :-

$\begin{array}{cccccc}\mathrm{AB} & \mathrm{BC} & \mathrm{FG} & \mathrm{GH} & \mathrm{HJ} & \text { Total length of model. } \\ 49 & 70 \cdot 5 & 54 \cdot 9 & 30.5 & 34 \cdot 1 & 119 \cdot 5\end{array}$

Now, for the reason which will presently become clear, the above intervals will be expressed as proportions, not of 119.5 but of 119.5 $\frac{119 \cdot 5}{1 \cdot 0-0 \cdot 22}$ or $153 \cdot 5:-$

$\begin{array}{ccccc}\mathrm{AB} & \mathrm{BC} & \mathrm{FG} & \mathrm{GH} & \text { HJ } \\ .32 & .46 & .358 & .199 & .223\end{array}$

Referring back to Table III on page 739, it is seen that when the head comprises $\cdot 22$ of the body-length $\mathrm{L}_{\mathrm{B}}$, the proportions of the bodyintervals vary but little from those given. Thus, by stretching the model to a length of $119 \cdot 5$ units, approximately correct results for a fish whose head comprises $\cdot 22 \mathrm{~L}_{\mathrm{B}}$ are arrived at. The proportions of $\mathrm{GH}$ and $\mathrm{HJ}$ are admittedly not entirely accurate, but this is not surprising when it is remembered that by this time the broader features of metamorphosis are practically completed, and the fish is settling down to growth as an adolescent.

It must now be emphasised that the whole of the above considerations have been made possible by arranging that two parts of the model, viz., $\mathrm{AB}$ and $\mathrm{GH}$, shall remain at a constant absolute length under all circumstances of stretching. This postulates that in the process of metamorphosis, the distance from the back of the brain to the first dorsal ray, and the interval between the pelvics and the anus, remain unaltered in absolute length. Certain it is that if this hypothesis is used in the manner indicated above, reasonably accurate representations of successive phases of metamorphosis can be produced by a simple model. Conceivably these intervals may actually alter slightly in length as the fish grows and differentiates, but the increases cannot be anything approaching those made by other intervals, so that the assumption that there is no change in length is sufficiently accurate for practical purposes. 
This conclusion may serve to dispel a possible inclination on the part of the reader to criticise the foregoing paragraphs as a laborious consideration of highly theoretical models composed of tape and elastic, rather than as the presentation of precise data concerning the condition of actual fishes during their transition from larva to adolescent. It is easily realised that if the models lead to a correct understanding of the growth processes during metamorphosis, then it at once becomes possible for workers to foresee the effects of a change of circumstances upon the progress of transition. Any circumstance which will affect the relative proportions of the initial body-intervals of the larva, or the number of vertebra, or which at any subsequent stage of metamorphosis will influence the rate of growth of the body-intervals, must inevitably be reflected in the morphological character of the end-result, which in this case is the adolescent fish. The next section of this paper has to deal with this highly important side of herring investigations, and it will then become apparent how helpful the observations described above can be.

\section{Changes with Time of Sampling.}

It has already been pointed out that in a time-series of samples of metamorphosing herrings taken at Plymouth, the length of the fish at which any given phase of transition is reached varies over a wide range, and that there is much overlap in length-range from phase to phase. It is of the greatest practical importance to discover the significance of these differences. Only when this is properly appreciated can we hope correctly to use available biometric data in identifying local forms and races of herrings.

In an endeavour to present an orderly account on this important section of the work, I have found it convenient first to deal with the actual changes in length with time; next with coincident changes in the average number of vertebræ; and, finally, to discuss the results in general.

\section{Changes in Length.}

As the process of transformation from larva to adolescent herring is one of continuous alteration rather than of abrupt transformation, it is necessary to decide arbitrarily upon convenient criteria of stage of metamorphosis. In the present instance the method is to define the stages according to the positions of the fins and anus with respect to vertebræ. One might equally well adopt as a criterion the degree of development of other characters such as the keeled scales, the general body-scales, or the scheme of pigmentation, or even a combination of such characters. But as data on the relative positions of fins and anus have already been used in the study of the normal process of meta- 
morphosis, they may be made to serve here. There is one possible disadvantage in so doing, however, and that is, one must take into account the total number of vertebræ, for, as has already been shown, the relative positions of the fins and anus are dependent upon this factor. This necessitates the statistical treatment of data under separate vertebræ-classes.

On a number of occasions during the months of April and May, 1928, fifty specimens of each of four body-length groups were stained in alizarin, and the position of the fins and anus with respect to vertebræ noted. In Table IV the data on the position of the pelvics in the fishes with a total of 56 vertebræ are summarised :-

\section{TABLE IV}

\section{Position of Pelvics with Respect to Vertebre in Fishes} WITH 56 VERTEBR\&.

\begin{tabular}{|c|c|c|c|c|c|c|c|c|}
\hline \multirow{2}{*}{$\begin{array}{l}\text { Date } \\
1928\end{array}$} & \multirow{2}{*}{$\begin{array}{l}\text { Body: } \\
\text { length } \\
\text { group } \\
\text { (mm.). }\end{array}$} & \multicolumn{6}{|c|}{ Serial No. of vertebra under which pelvics lie. } & \multirow{2}{*}{$\begin{array}{c}\text { Total } \\
\text { No. of } \\
\text { specimens }\end{array}$} \\
\hline & & 24 & 25 & 26 & 27 & 28 & 29 & \\
\hline April 5 & 30 & $3 \cdot 5^{*}$ & $15 \cdot 5$ & $2 \cdot 0$ & - & - & - & 21 \\
\hline & ," & $2 \cdot 5$ & $19 \cdot 0$ & $10 \cdot 0$ & 0.5 & - & - & 32 \\
\hline May 1 & ," & $1 \cdot 0$ & $17 \cdot 0$ & $9 \cdot 0$ & - & - & - & 27 \\
\hline,$\quad 8$ & ," & - & $10 \cdot 0$ & 20.5 & 0.5 & - & - & 31 \\
\hline ", 18 & ", & - & $2 \cdot 5$ & $23 \cdot 5$ & $7 \cdot 0$ & - & - & 33 \\
\hline , $\quad 30$ & ” & - & - & $9 \cdot 5$ & $19 \cdot 5$ & $2 \cdot 0$ & - & 31 \\
\hline April 5 & 35 & $1 \cdot 0$ & $14 \cdot 0$ & $9 \cdot 5$ & 0.5 & - & - & 25 \\
\hline,$\quad 19$ & , & 0.5 & $1 \cdot 5$ & $14 \cdot 5$ & $9 \cdot 5$ & - & - & 26 \\
\hline May 1 & ," & - & $6 \cdot 5$ & $20 \cdot 0$ & $4 \cdot 5$ & - & - & 31 \\
\hline , & ", & - & 1.5 & $24 \cdot 0$ & $10 \cdot 0$ & 0.5 & - & 36 \\
\hline,$\quad 18$ & ", & - & - & 11.5 & 23.5 & $2 \cdot 0$ & - & 37 \\
\hline,$\quad 30$ & ," & - & - & 0.5 & $23 \cdot 0$ & $10 \cdot 0$ & $0 \cdot 5$ & 34 \\
\hline April 19 & 40 & - & - & $3 \cdot 0$ & $8 \cdot 0$ & - & - & 11 \\
\hline May 1 & ," & - & - & $8 \cdot 0$ & $23 \cdot 5$ & 1.5 & - & 33 \\
\hline ," & , & - & - & $1 \cdot 5$ & $16 \cdot 5$ & $10 \cdot 0$ & $1 \cdot 0$ & 29 \\
\hline 18 & ," & - & - & - & $15 \cdot 0$ & $14 \cdot 5$ & 0.5 & 34 \\
\hline 30 & ," & - & - & - & $5 \cdot 5$ & $19 \cdot 0$ & $2 \cdot 5$ & 27 \\
\hline May 8 & 45 & - & - & - & $3 \cdot 0$ & $23 \cdot 5$ & $3 \cdot 5$ & 30 \\
\hline 18 & ,, & - & - & - & $2 \cdot 0$ & $23 \cdot 5$ & $1 \cdot 5$ & 27 \\
\hline 30 & , & - & - & - & 1.5 & $21 \cdot 0$ & $7 \cdot 5$ & 30 \\
\hline
\end{tabular}

The data of the above table are shown graphically in Figure 12. It will be noticed that in each body-length group, the position of the pelvics tends to fall under a later vertebra in the series as date of sampling gets later. Thus in the $30 \mathrm{~mm}$. body-length group the pelvics on average lie beneath the 25th vertebra on April 5th, but under the 26th and even

\footnotetext{
* An entry of 0.5 was made when pelvics were below junction of two adjacent vertebræ.
} 
Table V. Number of Fish at following Stages of Development.

\begin{tabular}{|c|c|c|c|c|c|c|c|c|c|c|c|c|c|c|c|c|c|}
\hline & \multicolumn{2}{|l|}{$\begin{array}{l}\text { Date } \\
1928 .\end{array}$} & \multicolumn{2}{|c|}{$\begin{array}{l}\text { Body- } \\
\text { length } \\
\text { group. } \\
\text { (mm.) }\end{array}$} & $\begin{array}{l}\text { Total } \\
\text { No. of } \\
\text { Fish in } \\
\text { sample. }\end{array}$ & $\begin{array}{l}\mathrm{Pe} \\
6 \frac{1}{2} \\
\text { vert. }\end{array}$ & $\begin{array}{l}\text { lvies in } \mathrm{fr}_{\mathrm{r}} \\
6 \text { or } 5 \frac{1}{2} \\
\text { vert. }\end{array}$ & $\begin{array}{l}\text { ront of } \\
5 \text { or } 4 \frac{1}{2} \\
\text { vert. }\end{array}$ & $\begin{array}{l}\text { First Dor } \\
4 \text { or } 3 \frac{1}{2} \\
\text { vert. }\end{array}$ & $\begin{array}{l}\text { rsal Ray } \\
3 \text { or } 2 \frac{1}{2} \\
\text { vert. }\end{array}$ & $\begin{array}{l}\left(D^{1}\right) \text { by : } \\
2 \text { or } 1 \frac{1}{2} \\
\text { vert. }\end{array}$ & $\begin{array}{l}- \\
1 \text { or } \frac{1}{2} \\
\text { vert. }\end{array}$ & $\begin{array}{c}\text { Pelvics } \\
\text { beneath } \\
\left(\mathrm{D}^{1}\right) \\
0\end{array}$ & \multicolumn{4}{|c|}{$\begin{array}{l}\text { Pelvics behind First Dorsal Ray } \\
\begin{array}{cccc}\left(\mathrm{D}^{1}\right) & \text { by }:- & \\
\frac{1}{2} \text { or } 1 & 1 \frac{1}{2} \text { or } 2 & 2 \frac{1}{2} \text { or } 3 & 3 \frac{1}{2} \text { or } 4 \\
\text { vert. } & \text { vert. } & \text { vert. vert. }\end{array}\end{array}$} \\
\hline April 5 & . & . & . & & 50 & 6 & 28 & 16 & - & - & - & - & - & - & - & - & \\
\hline April 19 & . & . & . & & 51 & - & 8 & 20 & 15 & 7 & 1 & - & - & - & - & - & - \\
\hline May 1 & . & . & . & 30 & 52 & - & 7 & 14 & 22 & 6 & 1 & 2 & - & - & - & - & - \\
\hline May 8 & . & . & . & & 50 & - & 4 & 14 & 20 & 12 & - & - & - & - & - & - & - \\
\hline May 18 & . & . & . & & 46 & - & - & 3 & 2 & 15 & 21 & 4 & 1 & - & - & - & - \\
\hline May 30 & . & . & . & & 50 & - & - & 1 & 1 & - & 7 & 7 & 16 & 13 & 5 & 1 & - \\
\hline April 5 & . & . & . & & 50 & - & 3 & 18 & 26 & 3 & - & - & - & - & - & - & - \\
\hline April 19 & . & . & . & & 51 & - & 1 & 2 & 10 & 13 & 10 & 10 & 4 & 1 & - & - & - \\
\hline May 1 & . & . & . & 35 & 51 & - & - & 1 & 13 & 17 & 12 & 4 & 4 & - & - & - & - \\
\hline May 8 & . & . & . & & 49 & - & - & - & 7 & 19 & 15 & 2 & 4 & 2 & - & - & - \\
\hline May 18 & . & . & . & & 50 & - & - & - & - & - & 5 & 19 & 13 & 12 & 1 & - & \\
\hline May 30 & . & . & . & & 51 & - & - & - & - & - & - & - & 5 & 16 & 19 & 11 & - \\
\hline April 19 & . & . & . & & 15 & - & - & - & - & - & 1 & 3 & 7 & 4 & - & - & - \\
\hline May 1 & . & . & . & & 51 & - & - & - & - & - & 4 & 6 & 18 & 16 & 7 & - & \\
\hline May 8 & . & . & . & 40 & 50 & - & - & - & - & - & - & 1 & 9 & 17 & 21 & 2 & - \\
\hline May 18 & . & . & . & & 51 & - & - & - & - & - & - & - & - & 9 & 28 & 14 & - \\
\hline May 30 & . & & . & & 54 & - & - & - & - & - & - & - & - & - & 19 & 29 & 6 \\
\hline May 8 & . & . & . & & 51 & - & - & - & - & - & - & - & - & 1 & 25 & 25 & - \\
\hline May 18 & . & . & . & 45 & 50 & - & - & - & - & - & - & - & - & - & 21 & 28 & 1 \\
\hline May 30 & . & . & . & & 52 & - & - & - & - & - & - & - & - & - & 12 & 35 & 5 \\
\hline
\end{tabular}


the 27th towards the end of May. It is also seen that the fishes of the $30 \mathrm{~mm}$. body-length group taken on May 30th are, so far as the position of the pelvics is concerned, practically as far advanced as those of the 40-mm. group on April 19th.

This change in position of the pelvics with time is accompanied by corresponding changes in position of the dorsal fin and anus, as well as by changes in pigmentation and degree of development of the scales. Furthermore, similar results are obtained when the data for fishes having a total of 55 or 57 vertebræ are used instead of those of fishes with 56 vertebræ. Clearly, then, it may be said that the later the sample is taken the more advanced in metamorphosis are the individuals of any given body-length group, and in order further to impress this fact, Table $\mathrm{V}$ has been prepared showing the number of fishes in each of a series of classes according to the position of the first dorsal ray $\left(\mathrm{D}^{1}\right)$ relative to the pelvics.

Using the $30 \mathrm{~mm}$. bodylength group as an example, it is seen that the specimens taken on April 5th are all relatively early transition stages in which the pelvics are at least $4 \frac{1}{2}$ vertebræ in front of the first dorsal ray $\left(\mathrm{D}^{1}\right)$, whereas those of May

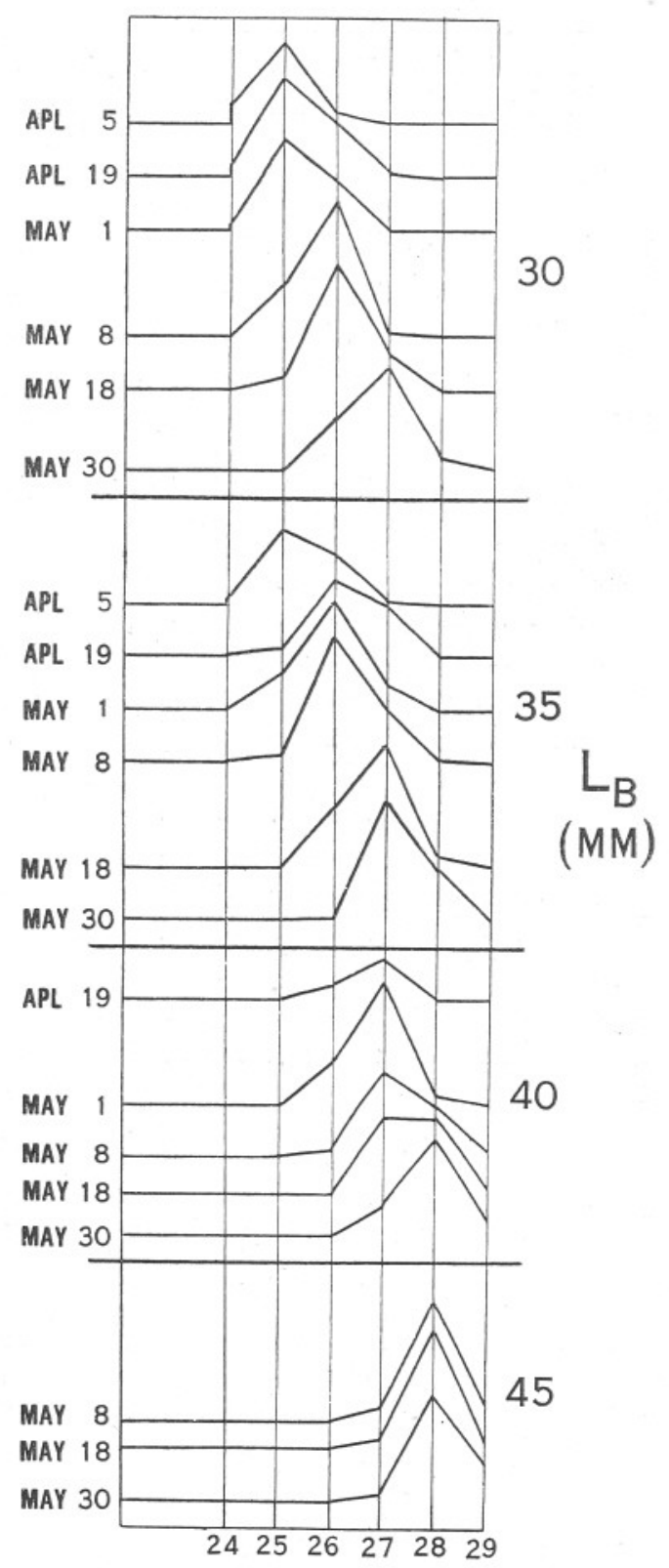

FIG. 12.-Graphic representation of data given in Table IV on page 745 . 
30th are much more advanced stages in which the pelvics are on average immediately beneath $\mathrm{D}^{1}$.

Stating the matter in another way, it may be said that for any stage of metamorphosis the length in later samples is shorter than that in earlier ones. This may be illustrated by extracting the data from Table $\mathrm{V}$ relative to the stage when the pelvics lie beneath the first dorsal ray :-

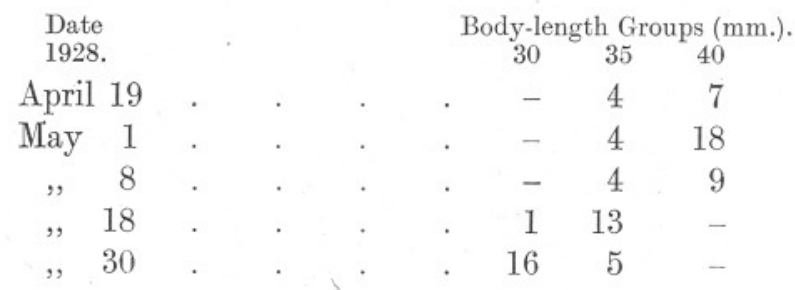

Thus, on April 19th and May 1st, this stage of development was not reached until a length of $40 \mathrm{~mm}$. had been attained; on May 18th specimens of $35 \mathrm{~mm}$. were at this stage, and on May 30th, those of the $30 \mathrm{~mm}$. group. Similar data could, if necessary, be produced to show that during the months of May and June of the year 1929, this phenomenon was again apparent, so that it may be regarded as a frequent and probably normal occurrence.

\section{Change in the Average Number of Vertebrce.}

It has been shown above that the individuals of a given length-group are more advanced in metamorphosis in later samples than in earlier ones. It is instructive next to consider the value of the average number of vertebræ in the same fishes. In Table VI relevant data are shown for individuals of the $30-\mathrm{mm}$. and $35-\mathrm{mm}$. groups :-

TABLE VI.

\begin{tabular}{|c|c|c|c|c|c|c|c|}
\hline \multirow{2}{*}{$\begin{array}{c}\text { Body-length } \\
\text { group } \\
\text { (mm.). }\end{array}$} & \multirow{2}{*}{$\begin{array}{c}\text { No. of } \\
\text { Vertebræ }\end{array}$} & \multicolumn{5}{|c|}{ Date of Sample (1928) } & \multirow[b]{2}{*}{$\begin{array}{r}\text { May } \\
30\end{array}$} \\
\hline & & $\underset{5}{\text { April }}$ & $\begin{array}{c}\text { April } \\
19\end{array}$ & $\underset{1}{\operatorname{May}}$ & $\underset{8}{\text { May }}$ & $\begin{array}{c}\text { May } \\
18\end{array}$ & \\
\hline \multirow[t]{5}{*}{30} & 54 & - & 1 & 1 & - & - & - \\
\hline & 55 & 26 & 15 & 17 & 13 & 7 & 14 \\
\hline & 56 & 21 & 32 & 27 & 31 & 33 & 30 \\
\hline & 57 & 3 & 3 & 5 & 6 & 5 & 2 \\
\hline & Average & $55 \cdot 54$ & $55 \cdot 73$ & 55.72 & $55 \cdot 86$ & $55 \cdot 95$ & $55 \cdot 74$ \\
\hline \multirow[t]{6}{*}{35} & 54 & 2 & 1 & - & - & - & - \\
\hline & 55 & 15 & 17 & 16 & 9 & 7 & 14 \\
\hline & 56 & 25 & 26 & 31 & 36 & 37 & 34 \\
\hline & 57 & 7 & 4 & 3 & 3 & 6 & 1 \\
\hline & 58 & - & 1 & - & - & - & - \\
\hline & Average & $55 \cdot 73$ & $55 \cdot 735$ & $55 \cdot 74$ & $55 \cdot 86$ & 55.98 & $55 \cdot 735$ \\
\hline
\end{tabular}


The data show that the average number of vertebræ does not remain constant throughout the series of samples; on the contrary, there is a definite tendency for it to rise as the sampling is later.

A number of instances might be given which would show that within the same day's sampling, the average number of vertebræ changes with the body-length group. The following two cases are worthy of mention because they demonstrate to a marked degree how the average may change :-

\begin{tabular}{|c|c|c|c|c|c|c|c|c|c|}
\hline \multirow{3}{*}{$\begin{array}{l}\text { Date of } \\
\text { Sample. }\end{array}$} & $\begin{array}{c}\text { No. of } \\
\text { Vertebræ }\end{array}$ & \multicolumn{8}{|c|}{ Body-length Group (mm.). } \\
\hline & & 30 & 35 & 40 & 45 & 50 & 55 & 60 & 65 \\
\hline & 55 & 1 & 2 & 10 & 17 & - & - & - & - \\
\hline \multirow{3}{*}{$\begin{array}{l}\text { May 26th, } \\
\quad 1927\end{array}$} & 56 & 28 & 30 & 31 & 28 & - & - & - & - \\
\hline & 57 & 21 & 17 & 8 & 5 & - & - & - & - \\
\hline & 58 & 1 & 1 & 1 & - & - & - & - & - \\
\hline \multirow{6}{*}{$\begin{array}{c}\text { June 25th, } \\
1928\end{array}$} & Average & $56 \cdot 44$ & $56 \cdot 34$ & $56 \cdot 00$ & $55 \cdot 76$ & & & & \\
\hline & 54 & - & - & - & - & - & - & 1 & 1 \\
\hline & 55 & - & - & - & - & 7 & 9 & 18 & 16 \\
\hline & 56 & - & - & - & - & 40 & 35 & 27 & 28 \\
\hline & 57 & - & - & - & - & 3 & 6 & 4 & 5 \\
\hline & Average. & & & & & 55.92 & $55 \cdot 94$ & $55 \cdot 68$ & 5.5 . \\
\hline
\end{tabular}

One particular point of interest is plainly demonstrated by the data for May 26th, 1927. It will be noticed that the average number of vertebræ for the individuals of the $30-\mathrm{mm}$. group is the highest and that for the 45-mm. group the lowest. It should also be noted that the fishes of the $30-\mathrm{mm}$. group are the least advanced in development, and those of the 45-mm. group almost completely metamorphosed. Thus, within the same sample, a lower average number of vertebræ coincides with a more advanced stage of metamorphosis.

\section{Significance of Results in "Racial Investigations."}

It is hardly necessary to point out that the observations described above raise questions of great significance to herring biologists engaged in what have come to be known as "racial investigations." Why should the length at any given phase of metamorphosis tend to decrease as the time of sampling gets later? Why, simultaneously, should the average number of vertebræ tend to rise? To what extent are these facts due to differences between the adult fishes which produced the larvæ, and how much is due to the variation in physical conditions under which the eggs were incubated and the larvæ developed? On his answers to these questions will depend an investigator's interpretation of those significant differences which he frequently observes between random samples of herrings. In the opinion of the present writer we cannot confidently assess the significance of these differences until we know from actual 
experiment the extent to which the biometric characters of a new generation may differ from those of their parents as the result of the physical conditions under which development takes place. Thus, in the present instance, who can say whether the diminishing length of a given phase of metamorphosis and the simultaneous increase in average number of vertebræ was due more to the fact that the larvæ had sprung from different parent-stocks, than, say, to the effects of contemporary changes of temperature over the area during the season of incubation and development of the larvæ? Past work has certainly shown that the spawning shoals visiting Plymouth waters are by no means uniform in morphological character; but it is equally true that the temperature undergoes marked change, falling first to a minimum and then gradually rising again. Larvæ incubated and developed at a relatively low temperature might be expected to require a longer time than those reared at a higher temperature to reach a certain stage; the size at which this stage is reached would probably be larger.*

In addition, there is some reason for supposing that at the lower temperature, the number of vertebræ would tend to be higher. Such expectations, if applied to the particular local circumstances, will produce results which fit the observed facts quite as reasonably as the hypothesis of purely hereditary influences. But in the absence of relevant knowledge, it is impossible to say how much either has played in producing the end-result. In general, therefore, although quite real biometric differences are observable between random samples of herrings, their interpretation is still open to question and will remain so until experimental work has yielded that fundamental knowledge which alone can render interpretation possible.

\section{LITERATURE CITED.}

1. FAGE, L. Engraulidæ, Clupeidæ. Report on the Danish Oceanographical Expeditions, 1908-10, to the Mediterranean and adjacent Seas. Vol. II, Biology, A.9, 1920.

2. Ford, E. Herring Investigations at Plymouth. I. Methods of Collection and Treatment of Data. Journ. Mar. Biol, Assoc., N.S., Vol. XV, No. 1, 1928.

* Gray (4, p. 129), for example, has shown experimentally that when trout eggs are incubated at low temperatures the embryos at the moment of hatching are significantly larger than those hatching from eggs which have been incubated at higher temperatures. Increasing the temperature of incubation increases the growth-rate of the embryo, but, at the end of larval life, the full-time embryo is smaller than after slower development at a lower temperature. At higher temperatures, a larger proportion of the available yolk is required for the maintenance of the embryo, leaving a smaller proportion available for the formation of new tissue. 
3. Ford, E. Herring Investigations at Plymouth. IV. The Growth of Young Herrings in the Neighbourhood of Plymouth. Journ. Mar. Biol. Assoc., N.S., Vol. XV, No. 1, 1928.

4. Gray, J. The Growth of Fish. III. The Effect of Temperature on the Development of the Eggs of Salmo fario. British Journ. Exp. Biol., Vol. VI, No. 2, 1928.

5. Lebour, M. V. The Larval and Post-Larval Stages of the Pilchard, Sprat and Herring from Plymouth District. Journ. Mar. Biol. Assoc., N.S., Vol. XII, No. 3, 1921.

6. Percival, E. A Report on the Fauna of the Estuaries of the River Tamar and the River Lynher. Journ. Mar. Biol. Assoc., N.S., Vol. XVI, No. 1, 1929.

TABLE VII.

\begin{tabular}{|c|c|c|c|c|c|c|c|c|c|c|c|}
\hline $\begin{array}{c}\text { Position } \\
\text { of Pelvics. } \\
\text { No. of } \\
\text { specimens } \\
\text { in which } \\
\text { pelvics lie } \\
\text { beneath } \\
\text { vertebre } \\
\text { as under. }\end{array}$ & $\begin{array}{l}\text { Total } \\
\text { No. } \\
\text { of } \\
\text { verte- } \\
\text { bræ. }\end{array}$ & $\underset{24}{\text { No. }}$ & $\begin{array}{c}\text { of Speci } \\
25\end{array}$ & $\begin{array}{l}\text { Positio } \\
\text { mens in } \\
26\end{array}$ & $\begin{array}{c}n \text { of } 1 \text { st } \\
\text { which } \mathrm{D} \\
27\end{array}$ & $\begin{array}{l}\text { Dorsal R } \\
\text { lies ab } \\
28\end{array}$ & $\begin{array}{c}\text { ay }\left(D^{1}\right) \\
\text { ve vert } \\
\quad 29\end{array}$ & $\begin{array}{c}\text { bræas } \\
30\end{array}$ & der. & Totals. & $\begin{array}{c}\text { Position } \\
\text { of } \mathrm{D}^{1} . \\
\text { Working } \\
\text { means." }\end{array}$ \\
\hline 24 & & - & - & - & - & 1 & 3 & 9 & 1 & 14 & $29 \cdot 21^{*}$ \\
\hline $24-25$ & & - & - & - & - & - & $4 \frac{1}{2}$ & 9 & $1 \frac{1}{2}$ & 15 & $29 \cdot 10$ \\
\hline 25 & & - & - & - & - & 7 & $20^{\circ}$ & 17 & 4 & 48 & $28 \cdot 87$ \\
\hline $25-26$ & & - & - & - & 1 & $4 \frac{1}{2}$ & 8 & $2 \frac{1}{2}$ & - & 16 & $28 \cdot 25$ \\
\hline 26 & & - & $1 \frac{1}{2}$ & 6 & 13 & 17 & $12 \frac{1}{2}$ & 1 & - & 51 & $27 \cdot 21$ \\
\hline $26-27$ & 55 & - & $1 \frac{1}{2}$ & $7 \frac{1}{2}$ & $5 \frac{1}{2}$ & $3 \frac{1}{2}$ & 1 & - & - & 19 & $26 \cdot 24$ \\
\hline 27 & & 1 & $33 \frac{1}{2}$ & 16 & $7 \frac{1}{2}$ & - & - & - & - & 58 & $25 \cdot 02$ \\
\hline $27-28$ & & $1 \frac{1}{2}$ & 12 & 8 & $\frac{1}{2}$ & - & - & - & - & 22 & $24 \cdot 84$ \\
\hline 28 & & $3 \frac{\pi}{2}$ & 37 & $24 \frac{1}{2}$ & - & - & - & - & - & 65 & $24 \cdot 82$ \\
\hline $28-29$ & & - & 5 & 3 & - & - & - & - & - & 8 & $24 \cdot 87$ \\
\hline 29 & & - & - & 3 & - & - & - & - & - & 3 & $25 \cdot 5$ \\
\hline Totals & & 6 & $90 \frac{1}{2}$ & 68 & $27 \frac{1}{2}$ & 33 & 49 & $38 \frac{1}{2}$ & $6 \frac{1}{2}$ & 319 & \\
\hline $24-25$ & & - & - & - & - & - & - & - & 1 & 1 & $30 \cdot 5$ \\
\hline 25 & & - & - & - & - & - & 3 & 4 & 4 & 11 & $29 \cdot 75$ \\
\hline $25-26$ & & - & - & - & - & - & $\bar{z}$ & $3 \frac{1}{2}$ & $4 \frac{1}{2}$ & 8 & $30 \cdot 06$ \\
\hline 26 & & - & - & - & - & $2 \frac{1}{2}$ & 5 & $8^{2}$ & $1 \frac{1}{2}$ & 17 & $29 \cdot 0$ \\
\hline $26-27$ & & - & - & - & - & $\frac{1}{2}$ & $\frac{1}{2}$ & 2 & - & 3 & $29 \cdot 0$ \\
\hline 27 & 57 & $\frac{1}{2}$ & $1 \frac{1}{2}$ & $11 \frac{1}{2}$ & $14 \frac{1}{2}$ & 3 & $2^{2}$ & 1 & - & 34 & $26 \cdot 32$ \\
\hline $27-28$ & & - & $\frac{1}{2}$ & $4 \frac{1}{2}$ & 5 & 3 & 1 & - & - & 14 & $26 \cdot 46$ \\
\hline 28 & & - & $9 \frac{1}{2}$ & $23^{-}$ & $9 \frac{1}{2}$ & $\frac{1}{2}$ & $\frac{1}{2}$ & - & - & 43 & $25 \cdot 56$ \\
\hline $28-29$ & & - & - & 6 & - & - & - & - & - & 6 & $25 \cdot 5$ \\
\hline 29 & & - & $\frac{1}{2}$ & 3 & $2 \frac{1}{2}$ & - & - & - & - & 6 & $25 \cdot 83$ \\
\hline $29-30$ & & - & 1 & - & - & - & - & - & - & 1 & $24 \cdot 5$ \\
\hline Totals & & $\frac{1}{2}$ & 13 & 48 & $31 \frac{1}{2}$ & $9 \frac{1}{2}$ & 12 & $18 \frac{1}{2}$ & 11 & 144 & \\
\hline
\end{tabular}

* For statistical purposes, the middle point of the 30th vertebra is regarded as point $29 \cdot 5$. 
TABLE VIII.

\begin{tabular}{|c|c|c|c|c|c|c|c|c|c|}
\hline $\begin{array}{l}\text { Position } \\
\text { of Pelvics. } \\
\text { No. of } \\
\text { specimens } \\
\text { in which } \\
\text { pelvies lie } \\
\text { beneath } \\
\text { vertebre } \\
\text { as under. }\end{array}$ & $\begin{array}{c}\text { Total } \\
\text { No. of } \\
\text { verte- } \\
\text { bræ. }\end{array}$ & $\begin{array}{c}\text { No. o } \\
41\end{array}$ & pecime & $\begin{array}{c}\text { Positic } \\
\text { in whic } \\
\text { as u } \\
43\end{array}$ & $\begin{array}{l}\text { Anus } \\
\text { Inus lie } \\
\text { er. } \\
{ }_{44}\end{array}$ & $\begin{array}{c}\text { eneath } \\
45\end{array}$ & $\begin{array}{l}46 \\
46\end{array}$ & Totals. & $\begin{array}{l}\text { Position } \\
\text { of Anus. } \\
\text { Working } \\
\text { means." }\end{array}$ \\
\hline $\begin{array}{c}24 \\
24-25 \\
25 \\
25-26 \\
26 \\
26-27 \\
27 \\
27-28 \\
28 \\
28-29 \\
29\end{array}$ & 55 & $\begin{array}{c}- \\
- \\
- \\
- \\
8 \\
4 \frac{1}{2} \\
10 \frac{1}{2} \\
2 \frac{1}{2} \\
3 \frac{1}{2} \\
- \\
-\end{array}$ & $\begin{array}{c}1 \\
1 \\
11 \\
7 \frac{1}{2} \\
30 \\
8 \frac{1}{2} \\
44 \\
15 \frac{1}{2} \\
46 \frac{1}{2} \\
5 \\
\frac{1}{2}\end{array}$ & $\begin{array}{c}2 \frac{1}{2} \\
6 \\
21 \frac{1}{2} \\
6 \frac{1}{2} \\
11 \\
5 \frac{1}{2} \\
5 \frac{1}{2} \\
4 \\
14 \\
3 \\
2 \frac{1}{2}\end{array}$ & $\begin{array}{c}8 \frac{1}{2} \\
6 \\
12 \\
2 \\
2 \\
\frac{1}{2} \\
- \\
- \\
- \\
- \\
-\end{array}$ & $\begin{array}{l}1 \\
1 \\
2 \frac{1}{2} \\
- \\
- \\
- \\
- \\
- \\
- \\
- \\
-\end{array}$ & $\begin{array}{l}- \\
- \\
- \\
- \\
- \\
- \\
- \\
- \\
- \\
-\end{array}$ & $\begin{array}{r}13 \\
14 \\
47 \\
16 \\
51 \\
19 \\
60 \\
22 \\
64 \\
8 \\
3\end{array}$ & $\begin{array}{l}43 \cdot 23^{*} \\
43 \cdot 0 \\
42 \cdot 63 \\
42 \cdot 16 \\
41 \cdot 64 \\
41 \cdot 61 \\
41 \cdot 42 \\
41 \cdot 57 \\
41 \cdot 66 \\
41 \cdot 87 \\
42 \cdot 33\end{array}$ \\
\hline 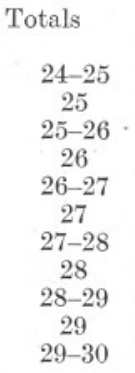 & 57 & $\begin{array}{l}29 \\
- \\
- \\
- \\
- \\
- \\
- \\
- \\
- \\
- \\
- \\
-\end{array}$ & $\begin{array}{c}170 \frac{1}{2} \\
- \\
- \\
- \\
-\frac{1}{2} \\
- \\
4 \frac{1}{2} \\
4 \\
6 \frac{1}{2} \\
- \\
- \\
-\end{array}$ & $\begin{array}{c}82 \\
- \\
\frac{1}{2} \\
- \\
4 \\
1 \\
22 \frac{1}{2} \\
9 \frac{1}{2} \\
32 \frac{1}{2} \\
5 \\
4 \frac{1}{2} \\
\frac{1}{2}\end{array}$ & $\begin{array}{c}31 \\
- \\
7 \\
5 \\
11 \\
1 \\
5 \frac{1}{2} \\
2 \frac{1}{2} \\
4 \\
1 \\
1 \frac{1}{2} \\
\frac{1}{2}\end{array}$ & $\begin{array}{l}4 \frac{1}{2} \\
1 \\
2 \\
4 \frac{1}{2} \\
1 \frac{1}{2} \\
1 \\
1 \frac{1}{2} \\
- \\
- \\
- \\
- \\
-\end{array}$ & $\begin{array}{l}- \\
\frac{1}{2} \\
\frac{1}{2} \\
- \\
- \\
- \\
- \\
- \\
- \\
- \\
-\end{array}$ & $\begin{array}{r}317 \\
1 \\
10 \\
10 \\
17 \\
3 \\
34 \\
16 \\
43 \\
6 \\
6 \\
1\end{array}$ & $\begin{array}{l}44 \cdot 5 \\
43 \cdot 75 \\
44 \cdot 05 \\
43 \cdot 29 \\
43 \cdot 5 \\
42 \cdot 62 \\
42 \cdot 41 \\
42 \cdot 44 \\
42 \cdot 67 \\
42 \cdot 75 \\
43 \cdot 0\end{array}$ \\
\hline Totals & & - & $15 \frac{1}{2}$ & 80 & 39 & $11_{\frac{1}{2}}$ & 1 & 147 & \\
\hline
\end{tabular}

* For statistical purposes, the middle point of the 44th vertebra is regarded as point $43 \cdot 5$. 